\title{
GOMMENT
}

\section{"VIEWER DISCRETION IS ADVISED": A STRUGTURAL APPROACH TO THE ISSUE OF TELEVISION VIOLENCE}

\author{
STEPHEN J. KIM†
}

Violence on T.V. is a problem, clearly, and a major contributor to the aura of dread and menace that permeates our culture. It's also the kind of problem Congress has every right to make a stink about and no business trying to remedy through legislation. ${ }^{1}$

\section{INTRODUCTION}

The issue of television violence presents a most unsettling dilemma-a conflict between the desire to protect the public from potentially harmful mass-communicated influences and the desire to preserve the electronic media's First Amendment rights. For forty years, television activists, legislators, social scientists, and members of the television industry have debated all sides of this issue. ${ }^{2}$ At one extreme, the television industry's most vehement

† A.B. 1990, Brown University; J.D. Candidate 1995, University of Pennsylvania; M.A. Candidate 1995, Annenberg School for Communication, University of Pennsylvania. I would like to thank Professors Edwin Baker, George Gerbner, Fritz Kubler, and Charles Wright for contributing their enormous expertise and enthusiasm to this Comment. I am also greatly indebted to the Comments Office, David Anderman, Jason DeSanto, Lisa Marino, and especially Julie Chung for their encouragement and careful editing of earlier drafts.

This Comment is dedicated to Andrew Jay Schwartzman and Gigi Sohn for their tireless devotion to the public interest, and to my parents for their love and support.

${ }^{1}$ Tom Shales, Family Hour: An Idea Whose Time Has Gone-and Come, WASH. Post, Oct. 20,1993, at B1 (author is a television critic for the Washington Post).

2 The debate over television violence is almost as old as the medium itself. For a chronological synopsis of various formal government inquiries into television violence, beginning with the 1954 Kefauver hearings before the Senate Subcommittee on Juvenile Delinquency, see LES BROWN, LES BROWN's ENCYCLOPEDIA OF TELEVISION 596 (3d ed. 1992). See also 1 HEALTH SERVs. \& MENTAL HEALTH AdMIN., U.S. DEP'T OF HEALTH, Educ. \& WELfare, Television AND SOCIAL Behavior: MEdia CoNTENT AND CONTROL (George A. Comstock \& Eli Rubinstein eds., 1972) [hereinafter TELEVISION AND SOCIAL BEHAVIOR]. For a review of the social science literature covering the television violence issue, see GEORGE GERBNER \& NANCY SIGNORIELLI, VIOLENCE AND TERROR IN THE MASS MEDIA: AN ANNOTATED BIBLIOGRAPHY 29-45 (UNESCO Reports \& Papers on Mass Communication No. 102, 1988). See also E. 
detractors argue that the effects of televised violence on society, especially on children, demand state intervention in the form of program content censorship. ${ }^{3}$ At the other extreme, industry advocates hoist the sacred banner of First Amendment rights while denying any correlation between violent programming and negative social effects. ${ }^{4}$ Between these poles, concerned observers who believe television violence has at least some negative impact on viewers, and yet would rather not risk the chilling effect of government content regulation, are left searching for more acceptable alternatives. $^{5}$

This Comment addresses the issue of television violence from a structural perspective which recognizes program content as the product of a complex web of market, organizational, legal, and occupational constraints that restrict creativity and innovation in the industry. Viewed from this perspective, the problem of television violence emerges as a symptom of a larger dilemma: the industry's reliance on the convention of violence is an example of how networks, advertisers, and producers have fallen into a cycle of

Barrett Prettyman, Jr. \& Lisa A. Hook, The Control of Media-Related Imitative Violence, 38 FED. COMM. L.J. 317, 322 nn.10-11 (1987) (listing congressional hearings on television violence).

${ }^{3}$ See, e.g., Television and Radio Program Violence Reduction Act of 1993, H.R. 2837, 103d Cong., 1st Sess. (requiring the Federal Communications Commission to prohibit violent television programming); Anne M. Kilday, Bryant Targets TV Violence, Criticizes Network Inaction, DALLAS MORNING NEws, Aug. 15, 1993, at 6A ("Basically what [H.R. 2837] does [is] treat violence like pornography . . . There's all kinds of things we don't put on TV, because in our society it is viewed as harmful." (quoting Rep. John Bryant, sponsor of H.R. 2837)).

4 See, e.g., James A. Albert, Constitutional Regulation of Televised Violence, 64 VA. L. REv. 1299, 1307 (1978) (quoting columnist Edith Efron's rejection of social science television violence studies); Joan Connell, Congress Putting the Heat on Television Violence; But Critics Call Action a "Big Chilh" Times-PiCAYUNe (New Orleans), Aug. 7, 1993, at A8 (quoting Leonard Hill, producer of Dead Before Dawn and I Can Make You Love $M e$, and a vehement objector to congressional threats to curb television violence, as saying: "[ $t]$ his is censorship, its effect on the whole industry will be chilling").

${ }^{5}$ See Tom Feran, Senator Rattles Saber to Cut TV Violence, PlaIN DEALER (Cleveland), Aug. 3, 1993, at 6A (noting that some TV insiders recognize a television violence problem yet fear government regulation); see also Shales, supra note 1, at B12 (advocating the creation of a "Family Hour" or "Family Viewing Time" which would be restricted to programs suitable for family viewing). Peggy Charren, founder of Action for Children's Television, states that

Congress frightens me more than the industry in this case. There are many reasons for the industry to shape up; to meet the needs of Congress I don't think is appropriate. I regard the First Amendment as more important that what children see on television. I am pro-choice in television programming.

Feran, supra, at $6 \mathrm{~A}$. 
dependence on formulae and routines to deal with uncertainty in the television market. Solutions to this problem require the removal of structural constraints rather than the imposition of additional content-based restrictions which, unfortunately, have recently gained public momentum.

Though the debate over television violence has raged almost since the first set flickered to life, ${ }^{6} 1993$ witnessed a remarkable shift in the balance of power in favor of would-be regulators. Perhaps because of increased public concern with the rising levels of violence in American society, ${ }^{8}$ legislators who were previously willing to rely on industry-initiated measures to deal with the violence problem were now poised to control the nation's video diet with government regulation. ${ }^{9}$ In 1993 , legislators introduced seven different proposals designed to attack the problem of television violence. ${ }^{10}$ If ever there was a time for alternatives that address both the public interest and constitutional concerns, it is now.

This Comment argues that the current legislative approach of content-based labeling regulation fails to address the structural roots of television violence. Above all else, television is a business, and any attempt to influence television content must treat it as such. Effective regulation of television violence cannot focus on isolated

${ }^{6}$ See Brown, supra note 2, at 596 (chronicling congressional hearings on television violence that began in 1954).

${ }^{7}$ See George Gerbner et al., Television Violence Profile No. 16: The Turning Point-From Research to Action 2-3 (1994) (unpublished manuscript, on file with author) (describing the ascent of television violence in the national political agenda).

${ }^{8}$ According to an MTV poll of 16- to 29-year-olds, the issue of violence surpassed jobs and the economy as the most pressing problem facing young people in 1993. See Sheila Rule, The Pop Life, N.Y. TIMES, Jan. 26, 1994, at C13. Recent years have also seen an increase in incidents of violence by children. See Mike Capuzzo, The End of Innocence?: A Generation that Has Lost Its Way-and Its Childhood-to Violence, PHILA. INQUIRER, Nov. 14, 1993, at G1. Capuzzo wonders if 1993 should be remembered as the "Year of the Evil Child," because of the large number of well-publicized violent crimes involving children, including the case of two British boys who allegedly kidnapped, beat, and murdered two-year-old James Bolger on February 12, 1993. See id. Such events, along with a heightened preoccupation with the subject in the news and entertainment media, "ha[ve] caused parents and policymakers to voice alarm over the roots and causes of the seeming epidemic of violence by children." Id.

${ }^{9}$ Congressman John Bryant, sponsor of the Television and Radio Program Violence Reduction Act of 1993, H.R. 2837, 103d Cong., 1st Sess., explained that the networks' failure to take action to reduce violent programming on their own initiative prompted him to consider congressional action: "[T] hey are not going to do anything about it, obviously, so we are going to turn it over to the FCC." Kilday, supra note 3 , at $6 \mathrm{~A}$; see also Albert, supra note 4, at 1315 (describing the history of congressional inactivity in the television violence context as a "tradition of inertia").

${ }^{10}$ See infra part II.A. 
post hoc measures punishing the transmission of violent material, but must instead influence the structural incentives motivating television producers to rely on formula violence. Instead of targeting violence as a specific category of objectionable material, policymakers should develop broad-based strategies to promote diversity in television content by increasing the incentives to produce innovative nonviolent programming. ${ }^{11}$ This strategy skirts the dangers of content-based regulation and avoids the especially sticky problem of defining violence. ${ }^{12}$

In pursuing this strategy, policymakers should target not only broadcast television, but all forms of video media, including cable and satellite television, as well as emerging technologies (such as interactive video). ${ }^{13}$ The promise of new communications technologies provides an excellent opportunity for policymakers to reexamine the nation's basic information goals and the best means to attain them. ${ }^{14}$

Similarly, a comprehensive structural strategy for encouraging nonviolent program diversity should encompass all types of programming, not just fictional programming, which is the usual target of attacks on television violence. The contribution of tabloid news shows, reality crime programs, the evening news, and even

11 See Prettyman \& Hook, supra note 2, at 381 . The authors note that

[o]pinion polls indicate that the public favors a reduction in media violence, and yet viewers increasingly watch violent scenes in theatres and in their homes. ... What is clearly needed is public support . . . for research into whether any new kinds of programming can be devised that will provide successful competition to present-day violence.

Id.

12 See infra part II.C.

${ }^{13}$ An especially interesting spin-off of the television violence problem is the issue of violence in video games. At the same time that the debate over television violence was heating up in the Congress, video game manufacturer Acclaim released four home versions of "Mortal Kombat," the top grossing American video arcade game in 1992. See Philip Elmer-DeWitt, Too Violent for Kids?, TIME, Sept. 27, 1993, at 70. One journalist described the game's characters' "finishing moves" as "bloody, decapitating uppercut[s]," "electrocution," and punches through the chest that "rip out a still beating heart." Id. One character "likes to tear his foe's head off and hold it up in victory, spinal cord still twitching as it dangles from the neck." Id. Although this issue parallels the television debate in many ways, the topic is outside the scope of this Comment.

14 "At this critical moment in our national history, it is imperative to assess our basic tools as the United States goes forward into the new century to communicate and compete in the global marketplace." HENRY GELlER, FIBER OPTICS: AN OPPORTUNITY FOR A NEW POLICY? 7 (1991). 
televised sporting events ${ }^{15}$ to the violent face of television should be considered as well. ${ }^{16}$

Part I will briefly summarize the scope of the violence debate by outlining the various positions advocates have taken on the issue. There are many conflicting theories on why violent television is bad and each perspective produces its own notion of how violence should be reduced. This Comment will try to find the common ground between these perspectives and suggest strategies that accommodate as many different approaches as possible. ${ }^{17}$

Part II will provide an overview of the remarkable rise of television violence as a publicly debated issue in 1993. This Part of the Comment will pay special attention to the legislative assault on violent content.

Part III will present legal and policy arguments against the content-based labeling approach currently embraced by legislators working to reduce violence. This Part will argue that the labeling measures proposed in Congress during 1993 will (1) face serious First Amendment challenges in the courts; and (2) fail to address the root structural causes of television violence.

The basis for the second argument in Part III is set forth in detail in Part IV, which presents a view of television violence from a structural approach, examining the technological, legal, organizational, market, and occupational influences in the television industry that collectively shape the violent nature of the medium. Any attempt to reduce television violence must recognize and confront

${ }^{15}$ See Anna Quindlen, Time to Tackle This, N.Y. TIMES, Jan. 17, 1993, at 17 (noting that shelters for battered women report increased calls during and after televised football games, particularly on Super Bowl Sunday, which some shelters say is one of the busiest days of the year).

${ }^{16}$ Indeed, this type of approach acknowledges, and answers, the common (and legitimate) complaint that " $[t]$ he campaign against violence seems focused on primetime dramatic shows . . . but ignores the excesses of sleazy afternoon talk shows, local news reports that sensationalize violent crime and 'reality-based' programs that wrap violence and predatory sex in the mantle of journalism." Connell, supra note 4, at A8.

${ }^{17}$ This Comment will avoid engaging in an in-depth analysis of the validity of empirical evidence investigating the correlation between television violence and viewer effects. Instead, this Comment will recognize the different theories of opposition to violent programming and suggest that a structural approach promoting increased viewer choice in programming can satisfy many of these competing positions. This Comment will also skirt some of the equally troubling peripheral issues of television violence, including the tendency in entertainment programs to portray the perpetrators of violent acts as white males and their victims as "female, non-white, foreign-born or elderly." John Murray et al., Yes, Mayhem Does Echo in Our Lives, USA TODAY, Aug. 2, 1993, at 9A. 
these structural influences that encourage the production of violent materials.

Finally, Part V will build upon the analysis and framework of Parts III and IV to recommend areas where policymakers should aim to break the cycle of the television industry's reliance on violence and other program conventions.

\section{OVERVIEW OF THE ISSUE OF TELEVISION VIOLENCE}

\section{A. The Frequency of Violence and Its Effects}

The popular impression that violence is widespread in the television landscape is supported by empirical evidence investigating the subject. According to data collected through the annual Violence Index project at the Annenberg School for Communication at the University of Pennsylvania, although the total number of violent incidents on television has declined slightly in recent years, violence continues to pervade prime-time broadcast network television. ${ }^{18}$ During an average week of the 1992-1993 season, slightly more than half (fifty-two percent) of all major characters appearing in prime-time network shows were involved in acts of violence. ${ }^{19}$ Sixty-five percent of all prime-time fictional dramatic programs included violent material. ${ }^{20}$ Saturday morning children's animated shows continued to out pace other programming with ninety percent of such cartoons and eighty percent of cartoon characters involved in violence. ${ }^{21}$ The 1993 Violence Index also studied cable-originated programming, finding cable children's programming "substantially less" violent than broadcast fare. ${ }^{22}$ General cable-originated programming, however, rated more violent than comparable broadcast programming. ${ }^{23}$

${ }^{18}$ The Violence Profile study, part of the Cultural Indicators Project, began during the 1967-1968 television season and is a systematic compilation of television violence data that is analyzed and published in regular Violence Profiles. See George Gerbner \& Larry Gross, Living with Television: The Violence Profile, 26 J. COMM. 173, 174 (1976).

${ }^{19}$ See Gerbner et al., supra note 7, at 10. For the purposes of the Violence Index, "violence" is defined as "clear-cut, unambiguous, and overt episodes of physical violence-hurting or killing or the threat of hurting and/or killing in any context." Id. at 5. The matter of defining "violence" and its importance in the television debate is discussed infra part II.C.

${ }^{20}$ See Gerbner et al., supra note 7, at 6.

${ }^{21}$ See id.

${ }_{22}^{2} I d$. at 7.

${ }^{23}$ See id. 
Another study, released in late 1993 by North Dakota Senator Byron Dorgan, counted an average of ten violent acts per hour during a one-week period of prime-time network television ${ }^{24}$ and seventy-six incidents of violence per hour during a single Saturday morning of children's cartoons. ${ }^{25}$ A comparison between a dozen cable channels and the broadcast networks revealed that the network broadcasts averaged more violent acts per hour (11.3) than their cable counterparts (8.4). ${ }^{26}$

However, while the numbers suggest a common ground for critics of violence, the empirical evidence alone fails to reflect the diversity of opinion regarding the effect of so much violent material on viewers. The degree and nature of people's concerns over the amount of television violence vary widely. Generally, opponents of television violence fall into the following categories, which, although neither comprehensive nor exclusive, are intended to illustrate the diversity of theories motivating the criticism of television violence: ${ }^{27}$

24 See Marilynn Wheeler, TV Survey Finds 10 Violent Incidents Per Hour During Prime Time, PHILA. InQUIRER, Dec. 29, 1993, at F6. The survey, analyzing 150 hours of prime-time network television between September 28 and October 4, 1993, defined violence as "the deliberate and hostile use of overt force by one individual against another." Id.

${ }^{25}$ See id.

${ }^{26}$ See id.

${ }^{27}$ For a brief summary of some of the many arguments made in defense of television violence, see Albert, supra note 4, at 1306-07 (reporting industry executives' and journalists' criticism of empirical evidence linking television violence with viewer aggression); Thomas F. Baldwin \& Colby Lewis, Violence in Television: The Industry Looks at Itself, in TELEVISION AND SOCIAL BEHAVIOR, supra note 2, at 290, 298-363 (providing statements of producers, writers, and others responsible for the content of television programs explaining why they use violence in their programs); George A. Comstock, New Research on Media Content and Control (Overview), in TELEviSION AND SOCIAL BEHAVIOR, supra note 2, at 1, 22 (arguing that violent entertainment is "cathartic" and responsibly portrayed so that it actually discourages viewers from engaging in violent behavior).

Perhaps the most logically appealing retort to industry claims that television violence has no impact on viewers is the argument that, if content indeed has no effect, then the industry must be based on a sham:

The fundamental premise of television is based on at least one of two lies. If a 15-second commercial can prompt the viewer to buy (or vote), the 25 acts of violence per hour will likewise prompt the targeted viewers to similarly respond with violence. If television does sell what it promises, television is much worse for society than all the illegal and legal drugs you could name. If this is not true, then all TV advertising is sold on a fraudulent premise and a lot of stupid marketers have bought a lot of dead air space from crooked TV marketing departments. 
(1) Direct Correlation. At one extreme, many believe that exposure to television violence can lead to violent acts in real life. A recent report of the American Psychological Association's Commission on Violence and Youth reviewed the scientific literature on the subject of television violence and concluded that "there is absolutely no doubt that higher levels of viewing violence on television are correlated with increased acceptance of aggressive attitudes and increased aggressive behavior. ${ }^{28}$ Some advocates of a variation of this view rely less on scientific studies and more on anecdotal evidence that video violence can inspire impressionable viewers to imitate acts of violence. ${ }^{29}$

(2) Cultivation. Proponents of this perspective argue that television's influence on viewers is more pervasive than possible links to discrete individual acts of violence. Instead, they argue that television's effects operate on a much larger scale, shaping people's social constructions of reality. ${ }^{30}$ In modern society:

Robert Posch, What You Do Emerges From Who You Are, DiREcT MARKETING MAG., July 1993, at 43.

${ }^{28}$ Alison Bass, Report on Youth Violence Urges Prevention, BOSTON GlOBE, Aug. 10, 1993, at 1, 6; see also 1 COMMISSION ON VIOLENCE \& YOUTH, AMERICAN PSYCHOL. ASS'N, VIOLENCE \& YOUTH: PSYCHOLOGY'S RESPONSE 33 (1993).

${ }^{29}$ In the case of "imitative" violence, viewers directly mimic violent acts portrayed on television. See Prettyman \& Hook, supra note 2, at 381; Andrew B. Sims, Tort Liability for Physical Injuries Allegedly Resulting From Media Speech: A Comprehensive First Amendment Approach, 34 ARIz. L. REV. 231, 243-45 (1992); see also Zamora v. Columbia Broadcasting Sys., 480 F. Supp. 199, 203 (S.D. Fla. 1979) (rejecting theory that television violence was responsible for minor plaintiff becoming addicted and desensitized to violent behavior resulting in his killing an 83-year-old woman). The summer of 1993 saw several high-profile cases of this type of violence. In one, an Ohio boy set his house on fire, killing his younger sister, allegedly after viewing an episode of "Beavis and Butthead," an MTV cartoon in which the main characters play with fire. See Richard Zoglin, The Shock of the Blue, TIME, Oct. 25, 1993, at 71.

${ }^{30}$ This theory was first developed by George Gerbner and his associates at the University of Pennsylvania's Annenberg School for Communication. See Gerbner \& Gross, supra note 18, at 173, 178. Gerbner and his associates argue that:

[I]n contrast to the more usual statement of the problem, we do not believe that the only critical correlate of television violence is to be found in the stimulation of occasional individual aggression. The consequences of living in a symbolic world ruled largely by violence may be much more farreaching. ... TV violence is a dramatic demonstration of power which communicates much about social norms and relationships, about goals and means, about winners and losers, about the risks of life and the price for transgressions of society's rules. Violence laden drama shows who gets away with what, when, why, how and against whom. "Real world" victims as well as violents may have to learn their roles. Fear-that historic instrument of social control-may be an even more critical residue of a show of violence than aggression. Expectation of violence or passivity in the face of injustice 
[T]elevision is the central cultural arm of American society. It is an agency of the established order and as such serves primarily to extend and maintain rather than to alter, threaten, or weaken conventional conceptions, beliefs, and behaviors. Its chief cultural function is to spread and stabilize social patterns, to cultivate not change but resistance to change. Television is a medium of the socialization of most people into standardized roles and behaviors. Its function is, in a word, enculturation. ${ }^{31}$

Thus, television distorts viewers' perceptions of violence when it portrays disproportionate levels of violence and aggression compared to that in the real world. Violent programming cultivates fear and anxiety in its audience. The problem is compounded when the video diet is particularly violent and viewers are consuming such output in large doses.

(3) Desensitization. Others object to television's depiction of violence on the grounds that it desensitizes viewers to the negative effects of aggression. Because of the volume and casual manner in which television portrays violence, viewers are shielded from the pain and suffering which accompany actual acts of violence. "[T]here's a danger that a continuous diet of this sort of thing can eventually make us insensitive and impervious to the genuine article when we see it," warns one proponent of this view. ${ }^{32}$ "We're not talking about eliminating violence from television," explains Senator Paul Simon. "'We're talking about deglamorizing violence, about portraying it realistically. The positive message needs to be delivered that violence brings no pleasure."m33 Supporters of this argument also accuse the news media of irresponsibility in their reporting of crime stories, especially when reporters appear to exploit a "sensational" angle of an event. ${ }^{34}$

may be consequences of even greater social concern.

Id.

31 Id. at 175.

${ }^{32}$ Meg Greenfield, TV's True Violence, NewsweEk, June 21, 1993, at 72.

s3 Connell, supra note 4 , at A8.

s4 See Steven Gorelick, Cosmology of Fear, MEdIA STUD. J., Winter 1992, at 17, 24-25. Gorelick argues that to alleviate the news media's tendency to manipulate the shock value of violent crimes and to pander to audiences' urges for sensational explicit stories, the press should be more sensational and more explicit, in order to educate the public about the truly terrible nature of violent crimes:

[P]ull no punches, leave no doubts, forget the euphemisms. If body parts are involved, tell us which body parts. Readers and viewers might be offended by more detailed discussions of some crimes, but that's no excuse. This does not mean that the Eyewitness Crew should pursue ever more blood-soaked video for the 11 o'clock teaser; rather that journalists, 
(4) Ideology/Morality. Some critics argue that the prevalence of violence in the media, especially in popular entertainment, sends disturbing messages regarding the modern American experience:

[T] he message of such entertainment is not what the sociologists say it is-that violence is an effective way to solve problems, that human life is cheap. The message is that America is no longer the land of promise, that fear and not opportunity drives us, that the American dream is dead. ${ }^{35}$

In addition, some religious groups, such as the Amish, oppose televised violence on moral grounds. ${ }^{36}$

(5) Taste. Finally, at the other extreme, some viewers feel that violence as a general matter is acceptable on television, but that there is simply too much of it. These critics do not subscribe to, or even care about, the scientific evidence on the subject. They simply believe intuitively that there should be less violence on the air. Although opposed to the exploitive uses of gratuitous violence, many of these viewers shy away from the more extreme positions outlined above because, frankly, they admit to enjoying violent material, at least once in a while. As one critic concedes: "Personally, I don't like the fact that there's so much [media violence] these days, but boy, I love the movie 'Aliens,' especially the scene in which Sigourney Weaver straps on that robotic forklift outfit and beats the pulp out of the big alien wasp monster." ${ }^{\text {37 }}$

\section{B. Summary}

As these abstracts indicate, participants in the television violence debate differ widely in their notions of the exact effects of violence. This fact helps to explain why people who can agree that violent material is bad can still often disagree over the proper remedy to

whatever their medium, should explain the real horror of these crimes. I think people want to know, and people need to know, even if they don't want to. In other words, if you're going to be sensational, be responsibly sensational. Be clear. Don't make the story palatable. The real story usually isn't, and readers should know that.

Id. at 25.

${ }^{35}$ Pat Dowell, The Nightmare Factory, IN THESE Times, Sept. 20, 1993, at 30, 31.

${ }^{36}$ See John A. Hostetler \& Donald B. Kraybill, Hollywood Markets the Amish, in IMAGE ETHICs 220, 231 (Larry Gross et al. eds., 1988) (explaining that, from the Amish perspective, "violence is always wrong, even if contrived and shown on the screen for a noble purpose").

${ }^{37}$ Noel Holston, Censorship: Scary Stuff; In Opposing TV Violence, Some Ignore Full Picture, Star Tribune (Minneapolis), Nov. 3, 1993, at $1 \mathrm{E}$. 
the "problem" of televised violence-the nature of the "problem" changes depending on which perspective a person brings to the debate. A member of the desensitization camp, for example, might be satisfied to see programs depict violent acts so long as the ugly effects of those actions are presented with equal force. Such portrayals would not satisfy direct cause-and-effect proponents who believe violent material stimulates violent behavior no matter how responsibly it might be presented.

In light of this disagreement between various critics of television violence, communications policymakers should seek to find the common ground uniting these categories by advocating policies which aim to weaken industry reliance on violence as a convention designed to draw audiences for advertisers. This approach would increase the diversity of television programming in the hope that increased viewer choice and producer creativity will lead to the proliferation of responsible nonviolent programming. The creation of an environment in which levels of violence are reduced and viewers have greater choice in programming is a goal with which everyone concerned with violence can be satisfied.

\section{1993: TeleVision Violence TAKes Genter STAge}

\section{A. The Congressional Assault}

The year 1993 marked significant changes in not only Congress's attitude toward the need for legislative and administrative solutions to the television violence problem, but also in the industry's response to this latest round of attacks. ${ }^{38}$ One of the factors responsible for raising the stakes in the 1993 violence debate was the impending expiration of the Television Program Improvement Act of $1990,{ }^{39}$ which granted television network executives a threeyear antitrust exemption for the purpose of "developing and disseminating voluntary guidelines designed to alleviate the negative

${ }^{3 s}$ Apparently, public opinion toward television violence has changed as well. According to a recent Times Mirror poll, the percentage of Americans who consider television unduly violent rose from 49 to $72 \%$ during the past decade. See Harry F. Waters et al., Networks Under the Gun, NEwSWEEK, July 12, 1993, at 64, 65. Another survey, commissioned by the Corporation for Public Broadcasting, reported that eight out of 10 respondents believe television is too violent. See Nicole Carroll, Viewers Speak: TV Airs Too Much Violence, USA TODAY, Feb. 1, 1994, at D1.

${ }^{39} 47$ U.S.C. \$ 303c (Supp. III 1991). For an overview of the Act, see Julia W. Schlegel, The Television Violence Act of 1990: A New Program for Government Censorship?, 46 FED. COMM. L.J. 187, 193-95 (1993). 
impact of violence in telecast material. ${ }^{70}$ As the end of the threeyear term approached, Senator Paul Simon, sponsor of the 1990 Act, convened a series of hearings to assess the industry's performance under the Act. Even before the opening gavel sounded the start of the first hearing, however, Simon and others made clear their opinion that the industry had failed to take adequate advantage of its opportunity to reduce the violent nature of television voluntarily. ${ }^{41}$ In a historic Beverly Hills conference, Simon addressed 650 television writers, producers, and promoters in the most explicit terms: "Exercise some self-restraint or Congress will do it for you-and many of my colleagues want to go much further than is healthy for a free society. ${ }^{92}$

Between May and September of 1993, legislators introduced seven bills to deal with the problem of television violence: the Television Violence Report Card Act of $1993,{ }^{43}$ the Children's Television Violence Protection Act of $1993,{ }^{44}$ the Presidential Commission on TV Violence and Children Act, ${ }^{45}$ the Parents

${ }^{40} 47$ U.S.C. $\$ 303 c$ (c).

41 See Kilday, supra note 3, at $6 \mathrm{~A}$ ("'[W]e changed the anti-trust laws three years ago to let the networks deal with this in their own way ... . And they did nothing." (quoting Rep. John Bryant of Texas)). But see Joyce Price, Congress' Nudging Reduces Violence on Prime-Time TV, WASH. TIMES, July 29, 1993, at A6 (reporting statements of Senator Simon and George Gerbner tentatively acknowledging success of Television Violence Act of 1990 in reducing volume of violent material).

${ }^{42}$ Connell, supra note 4 , at A8.

${ }^{43}$ H.R. 2159, 103d Cong., 1st Sess.; S. 973, 103d Cong., 1st Sess. This bill would require the Federal Communications Commission $\left({ }^{4} \mathrm{FCC}^{\prime}\right)$ to rate the amount of violence appearing in cable and broadcast television programs and produce quarterly Television Violence Report Cards reporting the violence rating of specific programs and identifying their sponsors. See H.R. 2159, supra, § 3(a); S. 973, supra, § 3(a). Under this approach, its authors argue, the government does not limit what viewers can watch, but instead "bolster[s] the ability of families and communities to make these decisions themselves." H.R. 2159, supra, § 2; S. 973, supra, § 2.

${ }^{44}$ S. 943, 103d Cong., 1st Sess. This bill would require the FCC to establish standards under which television licensees and cable programmers would be required to run a video and audio warning as to the violent content of a program and its possible negative effects on children. See id. $\$ 3($ a). Violations would be punishable by fines of up to $\$ 25,000$ and would be considered in the renewal application process of television licensees. See id. $\S 4$. News broadcasts, sporting events, educational programming, and documentaries may be exempted from the advisory requirement at the FCC's discretion. See id. $\$ 5$.

${ }^{45}$ H.R. 2609, 103d Cong., 1st Sess. This bill would authorize formation of a commission to study the problem of television violence, particularly its alleged adverse effects on children, see id. $\S \S 3-4$, and present a final report summarizing its findings and presenting recommendations for "legislative, administrative, and voluntary actions" which would counter the effects of television violence. Id. § 8. Additionally, any recommendations should continue "to preserve our tradition of free expression." 
Television Empowerment Act of $1993,{ }^{46}$ the Television and Radio Program Violence Reduction Act of $1993,{ }^{47}$ the Television Violence Reduction Through Parental Empowerment Act of 1993,48 and a bill sponsored by Senator Carl M. Levin of Michigan. ${ }^{49}$

Although Congress failed to act on any of these bills during 1993, the mere introduction of these proposals established many legislators' intent to break from the script of earlier brushes with the television industry: this time lawmakers' threats of action against violent programming were backed by concrete schemes to regulate television content.

\section{B. The Industry Reaction}

More surprising than the increasingly credible threat of government action was the industry's response. For the first time in the history of the forty-year violence debate, members of the television community acknowledged a responsibility for dealing with the problem of violent material, ${ }^{50}$ even going so far as to agree to

\section{Id. $\S 4$}

${ }^{46}$ H.R. 2756, 103d Cong., 1st Sess. This bill would establish a toll-free telephone number for the collection of complaints, comments, and suggestions concerning violence on broadcast and cable television. See id. Summaries of this information would be published quarterly identifying the programs, stations and networks (broadcast and cable) prompting complaints. See id. §3(b). Complaints concerning individual stations would be forwarded to the appropriate licensee. See id. §3(c). During the summer of $1993, A B C$ established a private version of this bill through the $A B C$ Advisory Hotline, an " 800 " number providing callers with a recorded listing of $A B C$ programs carrying viewer advisories. The company received 4500 calls in its first four days of operation. See Steve Coe, $A B C$ to Viewers: Dial $M$ for Murder, BroAdCASTING \& CABLE, Aug. 2, 1993, at 16; Ellen Edwards, Congress Takes Aim at TV Violence: Bills Would Require "V-Chip," Regulation of Fiction Programs, WASH. POST, Aug. 5, 1993, at C1, C4.

${ }^{17}$ H.R. 2837, 103d Cong., 1st Sess. This bill would "require the [FCC] to establish standards to reduce the amount of programming which contains violence from broadcast television and radio." Id. at 1 .

${ }^{18}$ H.R. 2888, 103d Cong., 1st Sess. This bill would require new television sets to have built-in circuitry (known informally as the "V-chip") to allow viewers to block the display of violent programming. See id. §3. Broadcasters would have to run advisories before violent shows in addition to transmitting electronic signals that would trigger the V-chip in a receiver set to block violent programming. See id. \$2(a).

${ }^{49}$ S. 1556, 103d Cong., 1st Sess. This bill would require commercial broadcast television stations to maintain public records of complaints regarding violent commercials and program promotion advertisements.

${ }^{50}$ See Waters et al., supra note 38 , at 64 (' $[\mathrm{A}] \mathrm{fter} 40$ years of denial, despite more than 3,000 damning studies, the TV industry's biggest guns tacitly conceded that violence on television can indeed beget violence in real life."). 
impose voluntary violence ratings systems on programming. ${ }^{51}$ Speaking in the wake of the Beverly Hills conference, ${ }^{52}$ CBS programming chief Jeff Sagansky acknowledged that regardless of one's opinion on the accuracy of the scientific research on the effects of television violence, " $[\mathrm{t}]$ he fact of the matter is our society has gotten more violent. No matter what you believe about the studies, we've got to be part of the solution and in no way part of the problem. ${ }^{53}$ By the end of the summer, all four networks and fifteen cable services agreed to transmit viewer advisories before programs containing violent material. ${ }^{54}$

In addition to feeling the pressure from legislators, the networks might have agreed to these conciliatory steps because of a sense of growing public resistance to current levels of television violence. A 1993 Times Mirror poll found that fifty-nine percent of respondents were "personally bothered" by television violence, and eighty percent agreed that such violence is harmful to society. ${ }^{55}$ The very

${ }^{51}$ See Edmund L. Andrews, Cable Industry Endorses Ratings and Devices to Lock Out Violence, N.Y. TIMES, Jan. 22, 1994, at 1.

${ }^{52}$ See supra note 42 and accompanying text.

${ }^{53}$ Greg Braxton, TV Industry Warned: Curb Violence or Congress Will, L.A. TIMES, Aug. 3, 1993, at D1, D5; see also Verne Gay, Television Violence: 500 Industry Executives and Observers Gather in Hollywood to Discuss an Issue as Old as TV Itself, NEWSDAY, Aug. 1,1993 , at 7 ( ${ }^{\prime C}$ Clearly there is an awareness in this community that there is a problem. Obviously, society is too violent and, without stating that TV is the problem, it is certainly part of the problem."' (quoting Leslie Moonves, President of Warner Brothers Television)); David Levy, Guns, Sex and Network Secrets: The Plot by TV Execs to Bring Mayhem to the Tube, WASH. POST, Aug. 1, 1993, at C1. Levy states:

To some of us, the public fuss over violence on television seems awfully familiar-and for good reason. Much the same fuss was made 30 years ago by another collection of congressmen, facing another collection of network executives. The difference is that in 1993, the chieftains of network TV are at least admitting some of the blame. Thirty years ago, they stonewalled.

Id.

${ }^{54}$ See Verne Gay, Pulling the Plug on TV Chaos, NEwSDAY, Aug. 1, 1993, at 51; see also Kim McAvoy, TV Industry to Senate: Self-Regulation, Not Legislation, the Answer to Violence, BROADCASTING \& CABLE, May 24, 1993, at 14 (reporting pledge of all three major broadcast networks to reduce volume of violent programming for upcoming season). Several months after agreeing to air voluntary advisories for violent programming, however, at least one network announced that none of its new fall series would be carrying a warning label. See Steve Coe, No Wamings for Fall, Says Sagansky, BROADCASTING \& CABLE, July 26, 1993, at 20, 22 (reporting CBS's announcement that none of its fall series warranted parental advisories, although individual episodes might occasionally require warning labels).

${ }^{55}$ TIMES MIRROR CTR. FOR THE PEOPLE \& THE PRESS, TV VIOLENCE: MORE OBJECTIONABLE IN ENTERTAINMENT THAN IN NEWSCASTS 19 (1993); see also Christopher L. Phillips, Hollywood Takes Hill Heat on Violence, BROADCASTING \& CABLE, June 14, 1993, at 68 ("I think people are frustrated about crime, and this is 
public antiviolence campaign led by Rev. Donald Wildmon and the American Family Association against the controversial ABC show NYPD Blue was probably the most tangible expression of the sentiment measured in the polls. ${ }^{56}$

The networks' official concessions as to the possible negative societal effects of television violence, however, should not be read as signaling a shift in the industry's fundamental opposition to government intervention in television programming. Throughout the 1993 debate, industry officials relentlessly refuted any call for regulation with the traditional First Amendment refrain. ${ }^{57}$ Many also pointed to the politically opportunistic nature of the assault on television: "Nobody is going to lose points back home by going after television violence," mused one network executive who asked not to be identified. ${ }^{58}$ "It's like being against motherhood and apple pie. It's a shorthand for 'Are you for violence or against it," another unidentified executive added. ${ }^{59}$ Critics also pointed to

one way to deal with it." (quoting Jack Valenti, President of the Motion Picture Association of America)).

${ }^{56}$ NYPD Blue was at the heart of the 1993 debate over television violence. The $A B C$ police series, which, by the producer's own admission was partly motivated to push the edges of broadcast program standards, unleashed an angry anti-NYPD Blue campaign headed by media watchdog Rev. Donald Wildmon. See Richard Zoglin, Bochco Under Fire, TIME, Sept. 27, 1993, at 81. Fifty-seven ABC affiliates refused to run the series premiere which included a "jarring" scene in which a major character is shown being shot six times at close range. See Ed Bark, Cuffs Come Off "NYPD Blue" Tonight, DALLAS MORNING NEwS, Oct. 23, 1993, at 1C. To counter the affiliate defections, $\mathrm{ABC}$ began offering the series to independent and Fox network affiliates in markets where the $A B C$ affiliate had refused to air the show. See Greg Braxton, "NYPD Blue" Nabs ABC Viewers Despite Preemptions, L.A. TIMES, Oct. 26, 1993, at F4.

Perhaps as a result of the controversy over its content (each episode is preceded by a "viewer discretion is advised" warning), the show did remarkably well, garnering critical acclaim, selling out advertising, and landing among the 15 highest-rated shows each week. See id. at F1, F9; see also Jefferson Graham, "NYPD" Makes Its Case: No Ratings Blues for Controversial Series; Winning Over Affiliates and Viewers, USA TODAY, Oct. 26, 1993, at 1D-2D ('You can't buy the kind of PR Bochco got,' says Joel $M$. Segal of the McCann Erickson advertising agency. 'When you flag a movie or book as being titillating or violating somebody's standards, that draws 'em in. People become curious." $)$.

${ }^{57}$ See McAvoy, supra note 54, at 14 (reporting broadcast and cable officials testimony to Senate panel expressing preference for self-regulation over congressional action and unworkable ratings systems).

${ }^{58}$ Edwards, supra note 46, at C4; see also Feran, supra note 5, at 6A ("TV Violence has no constituency. If you are looking for a target that has no other side, you have found it." (quoting ABC News Correspondent Jeff Greenfield)).

${ }^{59}$ Edwards, supra note 46, at C4. Actor Tom Selleck has also been outspoken on this point, telling one reporter that it is "scapegoating to point to Hollywood or the news media or anybody else when really it rests with the individual and the 
what they saw as legislators' hypocritical reluctance to confront more controversial, and arguably more direct, influences on violence such as gun control. ${ }^{60}$

Some producers defended their work on the basis of market forces in a video environment undergoing dramatic technological changes. Indeed, competition from cable television, which is distributed on a pay-per-view or pay-per-channel basis and is not subject to the same FCC-enforced public interest standards as broadcast stations, forces broadcasters to use increasingly explicit material to capture the attention of viewers choosing from a growing array of channel options. ${ }^{61}$ In defending his show, Steven Bochco, producer of the controversial NYPD Blue, commented that " $[w]$ e have a new generation today .... What people watch is significantly more adult because they can access so much more. This show [NYPD Blue] gave us some additional colors to paint our pictures. ${ }^{762}$ In sum, 1993 saw a dramatic rise in the intensity and visibility of the television violence debate. Despite all the attention, however, neither the industry nor legislators managed to reach a consensus as to how to remedy the situation. In fact, defining the problem at all continued to be a significant matter of disagreement.

\section{What Is Violence? The Definition Debate}

As with beauty, violence is in the eye of the beholder. ${ }^{63}$

Television industry advocates consistently point out the difficult questions raised in defining violence. For example, George Gerbner's Violence Index study defines violence as "the overt expression of physical force against self or other, compelling action against one's will on pain of being hurt or killed, or actually hurting

individual's own sense of value and ethics." Canadians Adopt Code: Televised Violence Continues as Front-Burner Issue in Washington, Elsewhere, COMM. DAILY, Nov. 9, 1993, at 3 [hereinafter Canadians Adopt Code].

${ }^{60}$ See Thomas Tyrer, QE'A: Disney's Rich Frank, ElEC. MEDIA, Aug. 23, 1993, at 1,17 ("I am concerned when we have governmental bodies that want to take on television violence but refuse to get $\mathrm{AK}-47 \mathrm{~s}$ and Uzis and handguns off the streets.").

${ }^{61}$ See Rob Dreher, Simonizing the Tube: Senator Calmly Set His Sights on Controlling Violence on TV, WASH. TIMES, Aug. 1, 1993, at D1 ("[I]n a severely competitive TV market, cable violence ups the ante for broadcasters. Many in the TV business claim original cable programming like horrormeister John Carpenter's "Body Bags" ... stands to lure viewers away from relatively tame network fare.").

${ }^{62}$ Zoglin, supra note 56 , at 81.

${ }^{63}$ Marc Gunther, TV Violence: Who Knows What Is, What Isn't?, PHILA. INQUIRER, Nov. 1, 1993, at E1, E6. 
or killing. ${ }^{964}$ Critics have complained, however, that this definition disregards the context or tone of an act. ${ }^{65}$ For example, surveys of television violence which characterize shows based solely on a running tally of broadly defined violent acts may equate Bugs Bunny tripping Elmer Fudd, a sack during a Monday Night Football game, news footage of the Rodney King beating, and Rambo maiming yet another anonymous victim. ${ }^{66}$ Some critics argue that the impact on the viewer of violence will vary significantly depending on whether the action occurs on a children's cartoon, a televised sporting event, a news/documentary program, or an action/ adventure film, and they should not all be lumped together. ${ }^{67}$

${ }^{64}$ Gerbner \& Gross, supra note 18 , at 184.

${ }^{65}$ See Price, supra note 41, at A6 ("NBC welcomes responsible studies of TV violence,' NBC spokesman Joe Rutledge told the Associated Press. 'This bizarre bit of bean counting [the Gerbner Cultural Indicators Project] does not hold up to scrutiny.'"); Jessica Seigel, Many Viewers Agree TV Violence Is Harmful; But in What Context?, CHI. TRIB., Aug. 8, 1993, \$ 4, at 1 .

'They [the researchers] kept using the word 'graphic.' I still don't know what that means," said Christine Hikawa, vice president of standards and practices for $\mathrm{ABC}$. "When they compare Wile $\mathrm{E}$. Coyote [from the Road Runner cartoons] and 'I Spit on Your Grave,' [a movie in which a woman is gang raped] they lose credibility with me."

Id. (alterations in original).

In response to the controversy over his measurement techniques, Gerbner readily agrees that "[o]bviously, not all violence is alike," but that for the purposes of a massive empirical coding study like the Violence Index project, subjective standards are not possible, and the definition currently in use is a reliable and objective one. See Gerbner et al., supra note 7, at 8 . Gerbner adds that "continued squabbles about technical methodological details of definition and measurement deflect attention from more serious areas of agreement and consensus." Id.

${ }^{66}$ Equating such disparate acts fails to account for the context in which the violent acts occur. For the 1992-1993 season, the National Coalition Against Television Violence "rated the lighthearted 'The Young Indiana Jones Chronicles' as the most violent show . . . beating out grittier fare like 'Top Cops.' The group's system, based on a strict count of violent acts, apparently failed to consider tone." Seigel, supra note $65, \S 4$, at 1 .

${ }^{67}$ See, e.g., Price, supra note 41, at A6; Seigel, supra note 65 , § 4, at 1 . Indeed, the debate over the effects of cartoon violence is particularly contentious because of the possible impact on large audiences of children. Although the networks argue that these programs are harmless compared to dramatic depictions of violence, researchers such as Gerbner argue the opposite-that in fact because the violence is "sugarcoated" in a comedic package, the effect on children is even greater. See Seigel, supra note $65, \S 4$, at 1 ("Humor makes it [violence] go down more easily." (quoting George Gerbner of the University of Pennsylvania's Annenberg School for Communication) (alteration in original)); see also JOHN CONDRY, THE PSYCHOLOCY OF TELEVISION 89-91 (1989) (reviewing scientific research into effect of cartoon/comic violence on children); Gay, supra note 53, at 7 (" $[\mathrm{T}]$ he hottest area of contention is animation .... Some executives say the debate becomes ludicrous .... How can 
The definitional debate has serious implications for the constitutionality of potential regulations as well as their practical application. ${ }^{68}$ Regulations that define violence too broadly or vaguely run the risk of chilling the protected speech of television programmers. ${ }^{69}$ The American Civil Liberties Union ("ACLU") publicly opposes legislators' efforts to regulate television content: "'We have real problems with any attempt by government to curtail ideas presented on television. ... Under the Constitution, there's no such thing as a dangerous idea, and the solution to speech that bothers us is more speech of the kind that counters it." $"$ 70

Apparently, if legislators are aware of the definitional dilemma at all, their solution has been to avoid attempting to define what it is they want to regulate. Of the bills introduced during $1993,{ }^{71}$ only two include a definition of violent content. ${ }^{72}$ The remainder either delegate this weighty task to the $\mathrm{FCC}^{73}$ to the industry, ${ }^{74}$ or avoid the issue of definition altogether. ${ }^{75}$

the watchdogs seriously criticize something as innocuous as 'Tom and Jerry?' But some experts say violence on cartoons is . . . most pernicious of all because . . . its constant repetition trains children to perform violent acts.").

${ }^{68}$ On this point, civil liberty advocates and public interest attorneys share the concerns of industry members. See Gunther, supra note 63, at E6 (reporting definitional concerns of Arthur Kropp, President of People for the American Way, and Andrew Jay Schwartzman, Executive Director of the Media Access Project).

${ }^{69}$ See infra notes 77, 92-111 and accompanying text (discussing constitutional implications of definitional debate).

${ }^{70}$ Dreher, supra note 61, at D4 (quoting Robert Peck, a First Amendment specialist for the American Civil Liberties Union).

${ }^{71}$ See supra part II.A (discussing the bills introduced during 1993).

${ }^{72}$ See S. 943, supra note $44, \S 2$ (1) ("The term 'violence' means any action that has as an element the use or threatened use of physical force against the person of another, or against one's self, with intent to cause bodily harm to such person or one's self."); H.R. 2837, supra note 47, § 3(1) (same).

${ }^{73}$ See, e.g., H.R. 2159, supra note $43, \S 3$ (c) (requiring the FCC to rate programs and program sponsors).

${ }^{74}$ See, e.g., H.R. 2888, supra note $48, \S 2(8)-(10)$ (urging the industry to adopt the use of devices such as channel-blocking equipment and rating systems).

${ }^{75}$ See, e.g., H.R. 2609, supra note 45; H.R. 2756, supra note 46; S. 1556, supra note 49. This Comment uses the term "television violence" generically to describe actions falling under the Gerbner definition-with the caveat that all television violence might not have the same impact depending on context and tone. As is discussed below, one of the advantages of the strategies suggested in this Comment is that they generally avoid having to define "violence." See infra part III.C. 


\section{The Problem With CoNTENT-Based Regulation OF TELEVISION VIOLENCE}

The difficulty in defining violence points to the serious problem of the constitutionality of current efforts to curb violent material. To date, the legislative response of choice to the violence dilemma has been to propose legislation mandating special treatment (usually in the form of labeling or public documentation) of violent programming. ${ }^{76}$ This content-based approach, however, is misdirected in terms of both the law and policy. Although the courts might uphold the constitutionality of such direct regulation of protected speech, labeling laws raise First Amendment and policy concerns that cannot be ignored. ${ }^{77}$ Most importantly, the back-end content-based approach of labeling holds only limited promise in addressing the structural causes for the production of violent material. ${ }^{78}$

${ }^{76}$ Of the seven bills mentioned in Part II.A, at least three, the Television Violence Report Card Act, the Children's Television Violence Protection Act, and the Television Violence Reduction Through Parental Empowerment Act, would require either the FCC or other industry entities to rate programming for violence. See $\mathrm{S}$. 973 , supra note $43, \S 3(\mathrm{a})$; S. 943 , supra note 44 , $\$ 3($ a); H.R. 2888 , supra note $48, \S 3$. A fourth bill, the Television and Radio Program Violence Reduction Act, which would have the FCC establish standards to reduce the amount of violent broadcast programming, presumably would also require the Commission to evaluate program content for violence. See H.R. 2837, supra note 47, § 4(a).

77 For general discussions of the constitutionality of television violence regulations, see Albert, supra note 4, at 1317-44 (considering constitutionality of violence regulation strategies, including monitoring of violent content through existing FCC licensing mechanisms, application of the Fairness Doctrine to violent material, and promotion of nonviolent programming); Thomas G. Krattenmaker \& L.A. Powe, Jr., Televised Violence: First Amendment Principles and Social Science Theory, 64 VA. L. REV. 1123, 1261-96 (1978) (applying First Amendment principles to proposals to prohibit violent material, balance violence, equip receivers to block violent programs, and require warning advisories); Prettyman \& Hook, supra note 2, at 366-79 (rejecting application of "incitement" analysis to television violence); Emily Campbell, Comment, Television Violence: Social Science vs. the Law, 10 LOY. ENT. L.J. 413, 453-59 (1990) (discussing constitutional propriety of various government violence regulation schemes).

${ }^{78}$ The government's role in the implementation of the rating scheme is critical. A statute requiring the state to screen all programming for violent content obviously raises the most serious First Amendment concerns, as outlined below. Even if the power to decide which shows require labels were vested in an independent nongovernmental body, however, as currently proposed by the cable and broadcast industries, see Andrews, supra note 51, at 1, constitutional concerns might nevertheless persist. See Jane M. Friedman, The Motion Picture Rating System of 1968: A Constitutional Analysis of Self-Regulation by the Film Industry, 73 CoLUM. L. REv. 185, 206-35 (1973) (arguing for possible application of prior restraint, First Amendment, and Fourteenth Amendment doctrines to voluntary motion picture ratings system). Given the intensive public and private pressure on the industry during 1993, a 


\section{A. Labeling: Information or Restriction?}

Initially, one must confront the question of whether labeling statutes should be viewed as true content-based restrictions if the purpose and effect of such regulation is only to provide information to consumers, and not to prohibit expression. How a court characterizes labeling will largely determine the analysis and outcome of a constitutional review. ${ }^{79}$ Two rationales for treating labeling as a content-based regulation are apparent. The first is that requiring a violence advisory from a programmer imposes a direct penalty on expression. In Riley $v$. National Federation of the Blind, ${ }^{80}$ the Supreme Court considered legislation requiring professional fundraisers to disclose certain financial information to potential donors. ${ }^{81}$ The Court argued that " $[\mathrm{m}]$ andating speech that a speaker would not otherwise make necessarily alters the content of the speech. We therefore consider the Act as a content-based regulation of speech." 82

The Riley Court explicitly rejected the state's argument that a disclosure requirement warrants less careful scrutiny than traditional restrictions on expression. The Court stated: "There is certainly some difference between compelled speech and compelled silence, but in the context of protected speech, the difference is without constitutional significance, for the First Amendment guarantees 'freedom of speech,' a term necessarily comprising the decision of both what to say and what not to say." ${ }^{83}$

The second is that, although the lofty theoretical purpose of a labeling statute is to provide information and empower viewers, ${ }^{84}$

"voluntary" industry-initiated ratings system might not be entirely voluntary. Finally, from a policy standpoint, allowing the industry to regulate violence on its own terms through an independent system could be unwise because it enables the regulated entity to establish standards that are far less restrictive than what Congress would have passed, but not so permissive that legislators feel the need to intervene directly. The result, for the public interest, might be the end of debate with quite unsatisfactory results.

\footnotetext{
${ }^{79}$ See infra parts III.B-C.

80487 U.S. 781 (1988).

${ }^{81}$ See id. at 784-803.

82 Id. at 795 .

${ }^{83}$ Id. at 796-97; see also Talley v. California, 362 U.S. 60 (1960). In Talley, the Court held as void on its face an ordinance restricting the distribution of any handbill which failed to identify the name and address of its author or manufacturer. See id. at 65 . The Court stated that " $[t]$ here can be no doubt that such an identification requirement would tend to restrict freedom to distribute information and thereby freedom of expression." Id. at 64.

${ }^{84}$ See 139 CONG. REC. S5823 (daily ed. May 12, 1993) (statement of Sen.
} 
the practical consequence of such regulation might be to suppress violent expression. Because advertisers generally avoid associating with programming that is offensive or controversial, ${ }^{85}$ the violence label could become a stigma that effectively repels sponsors, ${ }^{86}$ leading the networks and stations to avoid airing shows that have a label or run the risk of receiving a label.

Furthermore, there is reason to doubt the truly "informational" nature of the labeling statute. In examining the motion picture industry's self-imposed rating system, one commentator questions the scheme's practical informational value: ${ }^{87}$

It appears that the rating system has stimulated ... many forms of extra-industry private censorship that simply could not occur in the absence of the $X$ and $R$ [ratings]. Under the rating system, personal and institutional judgment and criticism on a movie-bymovie basis are no longer necessary. Any motion picture rated X, regardless of its merit or social value, has been branded in the minds of many as obscene. ${ }^{88}$

For example, she argues, many newspapers refuse to carry advertisements for X-rated films, despite having run ads for similarly erotic films before the implementation of the rating system. ${ }^{89}$ Likewise, television networks, airlines, and hotels have refrained from exhibiting films branded with the $X$ and sometimes even the $R$ rating. ${ }^{90}$

Durenberger) (describing labeling bill as empowering measure designed to help consumers, particularly parents, make informed viewing choices); see also David Durenberger, I See No Reason We Should Not Warn Parents About the Harmful Effects That TV Violence May Have on Their Children, BROADCASTING \& CABLE, May 31, 1993, at 74 ("Warning about violent TV shows will help us keep this marketplace free and vigorous by increasing the information available to parents about the TV shows their children might see.").

${ }^{85}$ "One of the basic commandments of advertising is: 'Thou Shalt Not Offend.' An advertiser does not want to spend money to make enemies." Campbell, supra note 77, at 461 (footnote omitted).

${ }^{86}$ Initially, for example, advertisers shied away from ABC's controversial NYPD Blue, which had a warning label, because it contained explicit language, sexual situations, and violence. See Zoglin, supra note 56, at 81 (reporting a "wait-and-see" attitude on the part of advertisers towards the show). Even after the show proved itself as a ratings contender, mainstream advertisers, many of whom maintain specific content guidelines, refused to purchase time with the show. See Graham, supra note 56 , at 1D, 2D.

${ }^{87}$ See Friedman, supra note 78, at 202-06.

${ }^{89} I d$. at 202 (citation omitted).

${ }^{89}$ See id.

${ }^{90}$ See id. at 203-04. 
Labeling for television violence might have the same effect. An FCC violence rating procedure could displace the personal judgment of viewers who simply decide not to watch (or not to let their children watch) any program with a label. In the event a rating system were combined with the implementation of a technological V-chip program, which automatically blocks out shows carrying a violence label, this substitution of the FCC's program judgment for personal program judgment would be completely automatic. Thus, the practical effect of this system would be to censor programming based on its content, not merely to provide information. ${ }^{91}$

Alternatively, a court could take the position that labeling performs an informational, rather than a restrictive, function. From this perspective, labeling acts as a means for the government to increase the information available to consumers, enabling them to make better-educated program decisions. The fact that viewers use that information to avoid undesirable violent programs does not necessarily force the characterization that labeling is restrictive. Rather, the public should be able to choose what it wants to watch-and labeling simply aids individuals in those choices.

The characterization of labeling as restriction of information is likely to be the key issue in a court's constitutional analysis. As demonstrated below, that characterization will likely determine whether a labeling statute passes or fails constitutional muster.

\section{B. Labels as Content-Based}

To a court adopting the view that labeling requirements are content-based restrictions, First Amendment analysis would continue under the highest level of judicial analysis-strict scrutiny. ${ }^{92}$ To pass constitutional muster, the government entity

${ }^{91}$ These practical effects fall within the scope of traditional First Amendment analysis:

[T] he fact that no direct restraint or punishment is imposed upon speech or assembly does not determine the free speech question. Under some circumstances, indirect "discouragements" undoubtedly have the same coercive effect upon the exercise of First Amendment rights as imprisonment, fines, injunctions, or taxes. A requirement that adherents of particular religious faiths or political parties wear identifying arm-bands, for example, is obviously of this nature.

American Communications Ass'n v. Douds, 339 U.S. 382, 402 (1950).

${ }^{2}$ See Simon \& Schuster, Inc. v. New York Crime Victims Bd., 112 S. Ct. 501, 509 (1991) (applying strict scrutiny to content-based "Son of Sam" law); Sable Communications, Inc. v. FCC, 492 U.S. 115, 126 (1989) ("[To] regulate the content of constitu- 
offering the restriction must show that the legislation is necessary to fulfill a compelling state interest and is narrowly drawn to serve that interest without impacting other speech protected by the First Amendment. ${ }^{93}$ The outcome of this analysis often hinges on whether the speech at issue falls into one of several categories of subordinate expression that are not entitled to full First Amendment protection. $^{94}$ In general, while the courts have allowed significant state restrictions on subordinate classes of speech, restrictions on protected expression must meet extremely strict standards to pass constitutional muster. ${ }^{95}$

Because television violence clearly falls outside the traditional categories of subordinate speech, ${ }^{96}$ under a rudimentary applica-

tionally protected speech in order to promote a compelling state interest [the government must] choose[] the least restrictive means to further the articulated interest."); Perry Educ. Ass'n v. Perry Local Educators' Ass'n, 460 U.S. 37, 45 (1983) (requiring strict scrutiny in context of "public forums"); see also LAWRENCE TRIBE, AMERICAN CONSTITUTIONAL LAW $§ 12-3$, at 798-99 (2d ed. 1988) (discussing application of strict scrutiny analysis).

${ }^{93}$ See Sable, 492 U.S. at 126; Perry, 460 U.S. at 45.

94 The Court has held that a number of classes of expression are entitled to limited or no First Amendment protection. See, e.g., New York Times v. Sullivan, 376 U.S. 254 (1964) (defamatory speech); Posadas de P.R. Ass'n v. Tourism Co., 478 U.S. 328 (1986) (commercial speech); Virginia State Bd. of Pharmacy v. Virginia Citizens Consumer Council, 425 U.S. 748 (1976) (same); Chaplinsky v. New Hampshire, 315 U.S. 568 (1942) (fighting words).

${ }^{95}$ See, e.g., Police Dep't v. Mosley, 408 U.S. 92, 96 (1972) (stating principle of "equality of status in field of ideas" which prevents government from restricting expression based on content of that expression). The Court's disdain for contentbased legislation surfaced most recently in R.A.V. v. City of St. Paul, 112 S. Ct. 2538 (1992), which considered a city ordinance prohibiting bias-motivated symbolic speech. In striking down the ordinance, the Court articulated the principle that " [c]ontentbased regulations are presumptively invalid," even if applied within categories of speech traditionally held to be outside the protection of the First Amendment. Id. at 2542. In an especially controversial portion of his opinion, Justice Scalia explained that these categories of speech (such as defamation and obscenity) are not literally outside of the Constitution, but rather are permissibly regulated "because of their constitutionally proscribable content." Id. at 2543. Thus, St. Paul's attempt to restrict certain specific species of hate speech was immediately suspect despite the fact that the ordinance sought to punish a subclass of speech (fighting words) historically considered to be unprotected. See id. at 2543 ("Thus, the government may proscribe libel; but it may not make the further content discrimination of proscribing only libel critical of the government.").

${ }^{96}$ The Seventh Circuit has held, for example, that

Racial bigotry, anti-semitism, violence on television, reporters' biases-these and many more influence the culture and shape our socialization. None is directly answerable by more speech, unless that speech too finds its place in the popular culture. Yet all is protected as speech, however insidious. Any other answer leaves the government in control of all of the institutions 
tion of strict scrutiny analysis it appears a court could invalidate a labeling statute on the basis that it unconstitutionally restricts protected expression. Given the ongoing controversy over the precise effects of media violence and the problem of definition, the government would face a tough battle in demonstrating both its compelling interest and the required fit between means and ends. ${ }^{97}$

Under a strict scrutiny analysis, a labeling statute might arguably be saved by the fact that the expression involved falls within the broadcast context, an area in which the Court has repeatedly held that the special circumstances of the medium justify content-based restrictions. ${ }^{98}$ In particular, the Court has relied on the technolog-

of culture, the great censor and director of which thoughts are good for us. American Booksellers Ass'n v. Hudnut, 771 F.2d 323, 330 (7th Cir. 1985), affd, 475 U.S. 1001 (1986).

The only class of subordinate speech in which violent television content could arguably fall would be expression which incites violence. This position is tenuous, however, in light of the difficulty of proving television executives' intent to incite violence and the conflicting evidence linking television violence with tangible acts of real world violence. For a convincing rejection of the application of the Brandenburg "imminent lawless action" standard, see Brandenburg v. Ohio, 395 U.S. 444, 447 (1969), to media violence, see Prettyman \& Hook, supra note 2, at 374-79. In Winters v. New York, 333 U.S. 507 (1948), the Court considered a challenge to a state statute prohibiting the distribution of printed materials consisting primarily of criminal acts or accounts. See id. at 508-10. The antiviolence statute had been used against a bookdealer charged with intent to sell the magazine Headquarters Detective, True Stories from the Police Blotter. See id. at 508. Unfortunately, the Court did not reach First Amendment principles in the case, choosing instead to strike down the statute on Fourteenth Amendment void-for-vagueness grounds. See id. at 518-19.

${ }^{97}$ See Krattenmaker \& Powe, supra note 77, at 1134-70 (presenting detailed criticism of social science evidence and definitional problem as inadequate foundation for government regulation). The authors conclude:

In sum, we do not believe that the available evidence concerning the impact of televised violence on society can or should lead one to conclude that any foreseeable regulatory program designed to inhibit or channel violent programming would be worth the costs of its implementation or could be supported by any acceptable view of rational policy formulation.

Id. at 1170. But see Action for Children's Television v. FCC, 11 F.3d 170, 185 (D.C. Cir. 1993) (Edwards, J., concurring) (suggesting that empirical evidence of harmful effects of television violence is quite persuasive compared to the lack of evidence of harms related to indecent programming).

${ }^{98}$ See, e.g., National Broadcasting Co. v. United States, 319 U.S. 190, $226-27$ (1943) (upholding FCC authority to license broadcasters and regulate networks through chain broadcasting rules); Red Lion Broadcasting Co. v. FCC, 395 U.S. 367, 400-01 (1969) (upholding constitutionality of Fairness Doctrine); FCC v. Pacifica Found., 438 U.S. 726, 748-51 (1978) (upholding FCC authority to restrict the broadcast of indecent language); see also Communications Act of 1934, § 301, 47 U.S.C. $\S 301$ (1988) (granting FCC authority to regulate communications in the name of "public interest, convenience or necessity"); Richard B. Gallagher, First Amendment Guaranty 
ical scarcity of the broadcast spectrum as a justification for allowing the government to regulate broadcasting. ${ }^{99}$ In FCC v. Pacifica Foundation, ${ }^{100}$ the Court, by a five-to-four vote and on a slightly different rationale, upheld the Commission's authority to regulate indecent broadcast-radio programming to protect the interests of children. Specifically, the Court cited two factors justifying the restriction of indecency to hours when children are unlikely to be members of the listening audience: (1) the uniquely pervasive presence of the broadcast media in daily American life; (2) the easy access of children to broadcast materials. ${ }^{101}$ Because of the government's legitimate interest and statutory duty to regulate television content in the public interest, Pacifica tentatively suggests the constitutionality of labeling for violence.

Outweighing this factor, however, is the impact the definitional debate would have on the courts' analysis of the means-ends fit of a labeling regulation. On November 23, 1993, in the heat of the 1993 television violence debate, the U.S. Court of Appeals for the District of Columbia Circuit handed down the latest installment in a continuing five-year battle between the court and the FCC relating

of Free Speech and Press as Applied to Licensing and Regulation of Broadcast MediaSupreme Court Cases, 69 L. Ed. 2d 1110, §2(a) (1982) (discussing the unique characteristics justifying special application of First Amendment principles in broadcasting).

${ }^{99}$ The government's authority to regulate mass communication industries has come under increasing attack because of growing doubt over the scarcity rationale as a legitimate means for justifying regulation of the airwaves. With the advent of alternative technologies of mass communication, including cable, direct broadcast satellite, and fiber optic networks, many commentators have argued that the government can no longer justify regulating broadcasters to insure diversity in the communications industry. See, e.g., David L. Bazelon, FCC Regulation of the Telecommunications Press, 1975 DukE L.J. 213, 223-29; Mark S. Fowler \& Daniel L. Brenner, A Marketplace Approach to Broadcast Regulation, 60 TEx. L. REV. 207, 221-26 (1982); Murray J. Rossini, The Spectrum Scarcity Doctrine: A Constitutional Anachronism, 39 Sw. L.J. 827, $827-38$ (1985); Matthew L. Spitzer, The Constitutionality of Licensing Broadcasters, 64 N.Y.U. L. REv. 990, 1007-20 (1989); Jill A. Stern et al., The New Video Marketplace and the Search for a Coherent Regulatory Philosophy, 32 CATH. U. L. REv. $529,562-66$ (1983). Without the scarcity argument, the Court will certainly scrutinize the constitutionality of a labeling statute under a much more demanding standard than possible under the current regulatory framework. The District of Columbia Circuit has already approved the FCC's rejection of the scarcity rationale. See Syracuse Peace Council v. FCC, 867 F.2d 654, 661-64 (D.C. Cir. 1989), cert. denied, 493 U.S. 1019 (1990). More importantly, in FCC v. League of Women Voters, 468 U.S. 364 (1983), the Supreme Court openly invited the FCC and Congress to argue that the scarcity doctrine is now obsolete. See id. at 376 n.11.

100438 U.S. 726 (1978).

${ }^{101}$ See id. at 748-50. 
to various attempts to regulate broadcast indecency. In Action for Children's Television v. FCC, ${ }^{102}$ the D.C. Circuit invalidated a six a.m. to midnight ban on indecent material. ${ }^{103}$ Despite its finding that the government's objectives of "helping parents supervise their children," "protecting the well-being of vulnerable youth," and "shielding them from physical and psychological abuse" were "compelling," 104 the court held that the government's eighteenhour indecency ban was not "the least restrictive means to advance its interests in the protection of children." ${ }^{105}$ Specifically, the court cited (1) the lack of evidence justifying the choice of the hours between midnight and six a.m. as appropriate in assisting parents' supervision of their children's exposure to indecent material; ${ }^{106}$ (2) the government's failure to consider that its interest in preventing all minors from exposure to indecent material might be

10211 F.3d 170 (D.C. Cir. 1993) [hereinafter ACT III].

${ }^{103}$ See id. at 182-83 (invalidating the Public Telecommunications Act of 1992, Pub. L. No. 102-356, 106 Stat. 949). The Public Telecommunications Act also contained a special provision extending the safe harbor to 10 p.m. for public broadcasters who sign off the air before midnight. See $\$ 16(\mathrm{a}), 106$ Stat. at 954 . In two previous decisions, the D.C. Circuit struck down earlier attempts by the FCC and Congress to enforce measures channeling or prohibiting broadcast indecency. In Action for Children's Television v. FCC, 852 F.2d 1332 (D.C. Cir. 1988) [hereinafter ACT $n$, vacated, 932 F.2d 1504 (D.C. Cir. 1991), the D.C. Circuit struck down an FCC decision to shorten the "safe harbor" in which stations could permissibly broadcast indecent material. See id. at 1341 (overruling In re Pacifica Found., Inc., 3 F.C.C.R. 930, 932 (1987)). The shift in administrative policy to a midnight to six a.m. safe harbor, the court held, was unjustified by the agency record. See id.

Following $A C T I$, Congress entered the fray, passing an appropriations rider ordering the Commission to enforce a 24 -hour ban on indecent broadcasting. See Pub. L. No. 100-459, $\S 608,102$ Stat. 2186, 2228 (1988). In Action for Children's Television v. FCC, 932 F.2d 1504 (D.C. Cir. 1991) [hereinafter ACT II], cert. denied, 112 S. Ct. 1281 (1992), the D.C. Circuit rejected the ban, holding that not even Congress could ban indecent speech without providing for some sort of safe harbor period. See id. at 1509 . The court directed the FCC to resume the rule making proceeding it had begun after the ACT I. See id. at 1510. These issues included, inter alia, the extent of the government's interest in restricting broadcast indecency and the proper guidelines and justifications for determining the proper safe harbor period for children. See id.

Even before the FCC could begin to gather the information the court requested, Congress intervened once again, passing the legislation which precipitated ACT III. See $\$ 16(a), 106$ Stat. at 949 (requiring the FCC to promulgate a new rule barring indecent material during the broadcast hours from six a.m. to midnight).

${ }^{104}$ ACT III, 11 F.3d at 177.

${ }^{105}$ Id. The court continued: "[W]e conclude that the government did not properly weigh viewers' and listeners' First Amendment rights when balancing the competing interests in determining the widest safe harbor period consistent with the protection of children." Id.

${ }^{106}$ See id. 
outweighed by the First Amendment rights of older, mature children to view such material; ${ }^{107}$ and (3) the government's failure to balance the rights of adult audience viewers against the compelling interest in protecting children. ${ }^{108}$

Together, the D.C. Circuit's decisions relating to the regulation of broadcast indecency and its repeated insistence on complete evidentiary records supporting the specific details of indecency regulations demonstrate the high level of scrutiny that content-based regulation of protected speech faces in the courts. ${ }^{109}$ The D.C. Circuit's struggle to evaluate the fit between ends and means in attempts to regulate indecency would likely prove even more difficult in the violence context. Because of the diversity of theories on the effects of violence on viewers ${ }^{110}$ and the related problem of defining "violence," 111 Congress and the courts will be hardpressed to discover the "least restrictive means" of protecting viewers from violent content without at the same time chilling other speech. Without greater agreement on what the "problem" of television violence actually is, legislators face a nearly impossible task in trying to regulate in a manner the courts will accept.

\section{Labeling as Information}

A court deciding that violence labeling is properly characterized as informational would likely reach a different result. Because of the informational nature of label requirements, a court might choose not to view the regulation under traditional content-based strict scrutiny analysis, but instead treat it simply as a rule requiring programmers to disclose information beneficial to consumers. ${ }^{112}$

${ }^{107}$ See id. at 178-80.

${ }^{103}$ See id. at 181-82. The court opined that " $[w]$ hat [the government] should have been aiming at was a time when the risk of child viewing was low and yet adult viewers could exercise a meaningful choice to view the material while still awake." Id. at 182.

${ }^{109}$ For instance, in $A C T$ III, the court ruled that " $[t]$ he government must adduce data which permits a more finely tuned trade-off between adults' First Amendment rights and the government's interest in protecting children from indecent material as that interest varies in importance with their age." Id. at 180.

${ }^{110}$ See supra notes 27-37 and accompanying text (summarizing various classes of objections to television violence).

${ }^{111}$ See supra part 1.C.

${ }^{112}$ The government's disclosure requirements with respect to cigarettes, see 15 U.S.C. $§ \S 1331-1341$ (1988 \& Supp. IV 1992), and food and drug labels, see 21 U.S.C. $\$ 352$ (1988 \& Supp. IV 1992), are perhaps the most well-known examples of this type of regulation. 
Under such analysis, the likelihood of labeling statutes passing constitutional muster is quite high. In Meese v. Keene, ${ }^{113}$ the Court considered the constitutionality of the Foreign Agents Registration Act of $1938,{ }^{114}$ which required that certain foreign films designated as "political propaganda" be labeled as such when exhibited in the United States. ${ }^{115}$ The district court held the statute to be an unconstitutional abridgement of speech, primarily because of the public's likely negative response to the label "political propaganda." 116

The Supreme Court, however, rejected this analysis, arguing instead that the labeling requirement imposed no restriction on speech $^{117}$ and that exhibitors' proper response to possible suppressing effects of labeling should be countered with additional speech:

Congress simply required the disseminators of such material to make additional disclosures that would better enable the public to evaluate the import of the propaganda. The statute does not prohibit appellee from advising his audience that the films have not been officially censured in any way. Disseminators of propaganda may go beyond the disclosures required by statute and add any further information they think germane to the public's viewing of the materials. By compelling some disclosure of information and permitting more, the Act's approach recognizes that the best remedy for misleading or inaccurate speech contained within materials subject to the Act is fair, truthful, and accurate speech. ${ }^{318}$

The same "counter-speech" reasoning could apply to a violence label statute viewed from the informational perspective. Television networks and stations fearing the deterrent effect of broadly worded labels could expand its advisories to include specific explanations of the type and amount of violence in a show. The additional

${ }^{113} 481$ U.S. 465 (1987).

11422 U.S.C. $\S \S 611-621$ (1988 \& Supp. IV 1992).

${ }^{115}$ See 481 U.S. at $470-71$.

${ }^{116}$ See Keene v. Meese, 619 F. Supp. 1111, 1123-26 (E.D. Cal. 1985) (reasoning that requirement of "political propaganda" label reflected "a conscious attempt to place a whole category of materials beyond the pale of legitimate discourse"), rev'd, 481 U.S. 465 (1987).

${ }^{117}$ See 481 U.S. at 480 ("Congress did not prohibit, edit, or restrain the distribution of advocacy materials in an ostensible effort to protect the public from conversion, confusion, or deceit.").

${ }^{118} I d$. at $480-81$ (footnotes and citations omitted). 
information could soften the blow of a generic warning requirement.

For a court choosing to view labeling as informational, the Supreme Court's decision in Meese and the Court's special treatment of the broadcast television context make for a compelling argument for the constitutionality of advisory-type regulations. Even so, this type of response to the problem of television violence raises First Amendment concerns which, even if they fail to invalidate such statutes altogether, are weighty enough that policymakers should search earnestly for alternative means of restricting television violence.

Most importantly, the problem of definition must and will pervade the constitutional analysis of any attempt to regulate violent material. The dangers of vagueness and overbreadth abound in the violence context, especially in light of the continuing debate over how violent programming impacts on audiences. If the FCC adopted a technical definition, such as the one used in the Violence Index studies, ${ }^{119}$ opponents could argue that the definition sweeps too much into the violent category because it fails to account for the effect of context. If the FCC tried to describe the contextual elements that make violence harmful and warrant labeling, critics will point to the standard as unconstitutionally vague because it fails to give programmers adequate guidance as to what material warrants a rating and what does not. The result, critics would argue, is a chilling effect as producers avoid even skirting the government's ambiguous standard.

In sum, the constitutionality of warning requirements is unclear and depends largely on whether the courts characterize such statutes as informational or restrictive. Although cases such as Riley v. National Federation of the Blind ${ }^{120}$ and Talley v. California ${ }^{121}$ strongly suggest the determination that violence labeling are properly characterized as inappropriate state restrictions, Meese could provide support for the view of labeling as permissible informational intervention. Even if the statutes overcome the First Amendment hurdles related to labeling, however, the requirements may also be objectionable from a pure policy perspective.

${ }^{119}$ See Gerbner et al., supra note 7, at 6 .

${ }^{120} 487$ U.S. 781 (1988).

121362 U.S. 60 (1960). 


\section{Policy Considerations}

The policy objection to labeling statutes and other regulations which censor content is that these proposals fail to address the structural motivations for the proliferation of violent material. Instead, these proposals take a reactive stance to the problem in the hope that punishing violent output will deter its production. Labeling measures, for example, apply pressure on only one aspect of the structure by seeking to influence those advertisers concerned with avoiding controversial material. ${ }^{122}$ This approach has no effect on breaking the structural chain of other market, occupational, organizational, and legal influences that drive the creation of violent content. ${ }^{123}$ Networks will continue to order, and producers will continue to produce, violent materials as long as markets for them exist. In fact, the use of a label might actually increase the product's market value because of its potential to attract viewers interested in violent programming. ${ }^{124}$ Labeling requirements enforced in the domestic market are also unlikely to affect distributors' ability or incentive to continue to sell programs in international markets when labeling is not required.

Another problem with labeling, V-chip, or other so-called "parental empowerment" legislation is that such proposals require affirmative action on the part of parents and guardians to supervise children's viewing. If parents or guardians are unwilling or unable to play such an active role in monitoring their children's television habits, ${ }^{125}$ these measures are rendered ineffective while imposing

${ }^{122}$ Recent events, however, indicate the limited impact of this approach. Consider the experience of ABC's television show NYPD Blue. Despite the controversy surrounding the explicit sexual content and language in its premiere, see supra note 56 , the show sold out all advertising during its first month. See Braxton, supra note 56 , at F4, F9.

${ }^{123}$ The only structural impact labeling promises is to drive some advertisers from violent programming. The impact of this effect on actual program content is questionable. See Schlegel, supra note 39, at 214 (criticizing V-chip proposals because "a technical device is unlikely to address the central concerns of those who believe televised violence is a social ill, because lock boxes do not generate a reduction (or elimination) of televised violence").

${ }^{124}$ See Waters et al., supra note 38, at 64 ("The advisories are just a faster road map to the violent material. ... 'Kids channel surfing will stop immediately and say, "Hey, this is it! We don't even have to look for it." (quoting Terry Rakolta, Founder of Americans for Responsible Television)). It has been suggested that broadcasters could use labeling requirements as an excuse to show even more violent programming since, after all, viewers are being warned about the content. See id.

${ }^{125}$ See Schlegel, supra note 39, at 214 ("[P]arents might be unwilling or unable to supervise their children's television viewing even if the means to do so were readily 
serious free speech costs. The labeling approaches also assume that children are the only viewers affected by violent programs. Many opponents to television violence, including members of the cultivation and desensitization camps, argue that adults are also subject to the detrimental effects of such material. ${ }^{126}$

\section{Understanding the Production Process}

To develop effective strategies for reducing violence and increasing the diversity of television programming, policymakers need to understand the program production process and the reasons why it consistently creates so much unimaginative and violent material. Reactive measures such as content-based legislation fail to recognize the complex interaction of forces at play in the television production process. The examination of the television production process set out below stems from a structural analysis of the industry.

\section{A. The Production of Culture}

The "production of culture" perspective diverges radically from our romantic image of art as the product of the lone starving artist wielding a pen or paintbrush and toiling long hours by candlelight to bring her work to fruition. ${ }^{127}$ Today, mass produced works of art spring from complex industrial processes which often bring together hundreds of individuals, large corporate entities, legal constructs, organizational rules and conventions, and a myriad of other influences. ${ }^{128}$ In contrast to the romanticized artist who exercises complete control over her product from start to finish, the creator of a television program is subject to a dizzying array of influences-so much so that it is difficult to identify any single individual as the "artist" responsible for a show. Instead, a television program is the product of the collective effort of what Howard Becker has termed an "art world":

available."); see also Campbell, supra note 77, at 455 (pointing out that warning labels are ineffective with viewers who tune in late to a program and miss the advisory).

${ }^{126}$ See supra notes 30-34 and accompanying text (discussing the cultivation and desensitization theories).

${ }^{127}$ See HOWARD S. BECKER, ART WORLDS 1 (1982).

${ }^{128}$ See id.; see also Richard A. Peterson, Five Constraints on the Production of Culture: Law, Technology, Markeh Organizational Structure and Occupational Careers, $16 \mathrm{~J}$. POPULAR CULTURE 143 (1982). 
Art worlds consist of all the people whose activities are necessary to the production of the characteristic works which that world, and perhaps others as well, define as art. Members of art worlds coordinate the activities by which work is produced by referring to a body of conventional understandings embodied in common practice and in frequently used artifacts. The same people often cooperate repeatedly, even routinely, in similar ways to produce similar works, so that we can think of an art world as an established network of cooperative links among participants. ${ }^{129}$

Becker's art world model provides an uncannily accurate description of the television programming process, where programs are indeed the product of many individuals behaving according to well-established conventions and expectations. ${ }^{130}$

Similarly, Richard A. Peterson describes the production of culture perspective as one recognizing that "the nature and content of symbolic products are shaped by the social, legal and economic milieux in which they are produced." ${ }^{131}$ In particular, Peterson identifies five constraints which are useful in dissecting the web of influences affecting the production of culture: law, technology, the market, organizational structure, and occupational careers. ${ }^{132}$ Each of these constraints can operate either individually or in conjunction with others depending on the particular production process involved. ${ }^{133}$

In the realm of television, for example, the legal constraints of the FCC and copyright law both constrain television output. ${ }^{134}$

129 BECKER, supra note 127, at 34-35.

${ }^{130}$ See Herbert J. Gans, Popular Culture in America: Social Problem in a Mass Society or Social Asset in a Pluralist Society?, in SOcIAL PROBLEMS: A MODERN APPROACH 549, 553 (Howard S. Becker ed., 1966). Gans summarizes his criticism of popular culture into three parts:

$[M]$ ass culture is an industry organized for profit; . . . in order for this industry to be profitable, it must create a homogeneous and standardized product that appeals to a mass audience; and that this requires a process in which the industry transforms the creator into a worker on a mass production assembly line, where he gives up the individual expression of his own skills and values.

Id.

${ }^{131}$ Peterson, supra note 128, at 143.

132 See id.

${ }^{13 s}$ See id.

${ }^{134}$ For example, the FCC regulates the broadcasting of lottery information, obscenity, and profanity, see 47 C.F.R. $\$ \$ 73.1211,73.4165$ (1992), and the Copyright Act of 1976 limits the secondary transmission of copyrighted material, see 17 U.S.C. $\S \S 111,118-119$ (1988). 
Likewise, the market forces of advertisers; the organizational structure of the networks and production studios; and the occupational roles of individual producers, network executives, and program directors have an enormous impact on what is shown on television. ${ }^{135}$

\section{B. Money Talks: The Dual Market and Network Control}

I'm not interested in culture. I'm not interested in pro-social values. I have only one interest. That's whether people watch the program. That's my definition of good, that's my definition of bad..$^{136}$

Television is a business. From this perspective, the sentiments of network executives such as the one cited above make perfect sense. The number one priority in television is not to transmit quality programming to viewers, but to deliver consumers to advertisers. ${ }^{137}$ Yet, despite the single-minded drive for profit that steers this business, the industry is plagued by a remarkable feeling of uncertainty about what exactly draws viewers. Unlike traditional industries in which goods or services are distributed to a single market, the television industry operates within the framework of a dual product market. ${ }^{138}$ On one level, members of the television art world deliver shows (goods/services) to viewers (consumers) in the context of a program product market. ${ }^{139}$ In this market, producers expend their creative efforts trying to develop programs that people will enjoy enough to make time to watch. ${ }^{140}$ Success

${ }^{135}$ See infra parts IV.B-F (describing the universe of influences on the program production process).

${ }^{136}$ TODD GITLIN, INSIDE PRIME TIME 31 (1985) (quoting Arnold Becker, Vice President for Television Research, CBS).

${ }^{137}$ See MURIEl CANTOR, THE HollywOOd TV PRODUCER: HIS WORK AND HIS AUDIENCE 64 (2d ed. 1988). Cantor argues:

The decision-making process in the television industry has to be understood in the general construct of commercial television. The main function of the entertainment programs generally is to attract large audiences in order to sell products; therefore, if a show does not attract a large enough audience, it often will be dropped. The advertiser wants a certain number of viewers for his money; in fact, the "cost per thousand" viewers often determines whether the advertiser will stay with a show. The number of viewers usually is determined by the Nielsen ratings.

Id. The same is becoming more and more true in the news context as well. See Richard C. Wald, The News Marketplace: A Ride on the Truth Machine, GANNETT CENTER J., Spring 1987, at 7, 16-19.

${ }^{138}$ See ROBERT G. PICARD, MEdIA ECONOMICS: CONCEPTS AND IsSUES 17 (1989).

${ }^{139}$ See id.

140 See id. 
in this market is gauged primarily through viewership measures such as the Nielsen ratings. ${ }^{141}$

In the broadcast context, however, this program product market is illusory in the sense that viewers do not pay for the programs they receive from broadcasters. ${ }^{142}$ Because of broadcast television's status as a public good, ${ }^{143}$ viewers do not directly provide revenues for the industry. Therefore, performance in this market does not necessarily benefit industry members financially.

The second market in which the television industry participates is a related but conceptually separate advertising market where industry members attempt to deliver audiences to advertisers. ${ }^{144}$ These advertisers provide the bulk of industry revenues through their purchases of advertising time. ${ }^{145}$

To compete in this market, industry members cater to advertisers' desires to reach certain segments of society whose characteristics such as age, sex, and income make them especially attractive as potential consumers. ${ }^{146}$ Because broadcasters typically rely on advertising dollars as their primary source of revenue, programmers must tailor shows to meet advertisers' needs. ${ }^{147}$ In fact, network

${ }^{141}$ See Brown, supra note 2, at 393 (describing the Nielsen Company as a a company whose best-known service is the measurement of TV audiences and whose reports are recognized as the index to success or failure in TV programming").

${ }^{142}$ The cable or pay-service context obviously presents a different situation since viewers pay a fee to receive a program.

${ }^{143}$ See PICARD, supra note 138, at 18. A public good is one which users can consume without diminishing its availability for others. See id.

14 See id.

${ }^{115}$ See id. (explaining that "[a]lthough some observers may casually conclude that media sell space or time to purchasers of advertising, a more precise and descriptive explanation is that media sell access to audiences to advertisers").

${ }^{146}$ See CANTOR, supra note 137, at xxi (describing how network television targets "middle and especially the lower-middle economic strata in society (presumably those likely to use the everyday products such as the drugs, beauty aids, food and household items advertised), and there is no doubt that this large group is made up of most of the heavy viewers of primetime shows").

${ }^{147} \mathrm{Gitlin}$ argues that

[i]f prime-time TV seems senseless, that may be because we view it through the prism of old-fashioned standards. We may expect loveliness of language, expressive acting, shadings of performance, and intimations of depths rumbling beneath the surface. We import ideals of craft and quality from ages of artisanship, even from the teleplays of the fifties. And indeed craft and quality do survive, at least as ideals, among Hollywood's craftsmen and -women. The networks, though, have a prior objective. Although executives may not be allergic to what they deem quality, the networks as a whole aim to create not purposeful or coherent or true or beautiful shows, but audiences. Any other purpose is subordinated to the larger design of 
executives might alter elements of a show to increase its appeal to a particularly valuable audience. For example, Quinn Martin, acclaimed producer of such shows as The Untouchables, The Fugitive, and Barnaby Jones, once described the process by which a character killed in the pilot for a new series was written back into the story after "somebody" (presumably a network or studio representative) discovered the character's popularity with viewers during audience research testing:

Well, in the pilot that I wrote with the writer, we used a sevenfoot black man who had a kind of Cuisinart for a hand. It could make drinks, cut through things, really a gimmick, a very Bondian gimmick. That man was killed in the pilot....

But the black man tested very highly.... Somebody says, "That black guy with the hand tested so high, make him the good guy's assistant." ...

....

... There again, there's a decision made, pure and simple. The meter said the black man tests well. Bring him back. Stick him somewhere. No thought given to it, and everybody falls in line. That's just one of the areas that really disgusted me with television. They just put the money in their pocket and aren't thinking through what they're doing. The show will fail. ${ }^{148}$

In terms of the Peterson framework, ${ }^{149}$ then, the influence of

keeping a sufficient number of people tuned in. That is, after all, what advertisers pay for. That is why the shows so often look concocted, forced, to critics trained to spot internal niceties. The sophistication goes not so much into shows as into calculations about audience "flow" and composition.

GitLin, supra note 136, at 56. Advertisers exert similar influence over news programming. See Gary Cummings, The Watershed in Local TV News, GanNETT CENTER J., Spring 1987, at 40, 51 (chronicling development of narrowcasting in local news to meet advertisers need for discrete audiences).

The critical importance of ratings demographics is particularly evident in the way program producers market their shows. Trade press advertisements for programs, in contrast to advertisements directed at viewers, rarely tout shows' plot lines or even star characters. Rather, typical trade press ads usually appear more like a spreadsheet and list shows' ratings performances in "key target [demographics]." See BROADCASTING \& CABLE, July 26, 1993, at 8-9, 11-15, 28-29 (containing examples of industry program series advertisements).

${ }^{118}$ Horace NeWCOMB \& Robert S. Alley, THE Producer's MEdium: CONVERSATIONS WITH CREATORS OF AMERICAN TV 68 (1983). The influence of advertising on media content is equally troubling in the news context. See Bazelon, supra note 99, at 229-34 (discussing negative impact of advertising and business interests generally on broadcast news judgment).

${ }^{149}$ See supra notes $131-35$ and accompanying text. 
the dual product market environment framework is both a market and an organizational constraint. In the course of adapting to the changing demands of viewers and advertisers, the networks have developed routines and conventions to adjust their shows to the vagaries of market demand and increasing competition among themselves. ${ }^{150}$ The extensive use of Nielsen ratings, focus groups, and other audience research, such as the pilot testing alluded to in the Quinn Martin example above, are examples of empirical devices the networks have devised to measure performance and demand. In the face of an ever increasing number of video outlets, such as expanding cable, satellite, and interactive television systems, programmers are seeking more reliable and precise measures with which to capture smaller, more fragmented segments of the viewing audience. ${ }^{151}$

Communications researcher Todd Gitlin describes this reliance on the numbers as the "logic of rationalization." 152 In an industry where the turnover of shows is rapid ${ }^{153}$ and the cost of programs

${ }^{150}$ For an extensive discussion of empirical and nonempirical methods of research and program analysis in electronic mass media industries, see ROGER D. WIMMER \& JOSEPH R. DOMINICK, MASS MEDIA RESEARCH: AN INTRODUCTION 280-309 (3d ed. 1991). See also GrruIN, supra note 136 , at 48 ('Indeed, the 'overnights' were the fruit of a technology Nielson would probably not have developed had competition-crazed networks not created a market for it.").

For a historical perspective on the rise of network control and rationalization, see Thomas Schatz, Desilu, I Love Lucy, and the Rise of Network TV, in MAKING TElevision: AUTHORSHIP AND THE PRODUCTION PROCESS 117 (Robert J. Thompson \& Gary Burns eds., 1990) [hereinafter MAKING TeLEvisION]. Schatz argues that

[b]y the mid-1960s, the networks had a lock on TV programming and Hollywood's "creative community," from the studio powers to the struggling independents, were relegated to mere subcontractor status. TV's penetration was well over 90 percent of American households, and network executives coined terms like "least objectionable programming" and "lowest common denominator" in their tireless efforts to maximize audience shares and revenues. Not surprisingly, programming strategies grew increasingly conservative and predictable as the experimentation and innovation of the 1950 s gave way to standard operating procedure.

Id. at 132-33.

${ }^{151}$ See WIMMER \& DOMINICK, supra note 150 , at 300 ("' $[1] n$ the modern world, where the business environment is hyper-competitive, and where the consumer choices are increasing almost exponentially daily, it is no longer wise to base even relatively minor decisions on either experience or intuition." (quoting Jim Ehrhorn, Operations Manager of WSBA-AM in York, Pennsylvania)).

${ }^{152}$ GITLIN, supra note 136, at 32 .

${ }^{153}$ Network executives displayed their skittishness earlier than usual in the 19931994 season. ABC pulled its new comedy series The Paula Poundstone Show off the air after only two episodes; South of Sunset, a CBS private-eye drama featuring rock singer Glen Frey, premiered and ended in one episode. See Jonathan Storm, Now You See 
is high, ${ }^{154}$ uncertainty runs rampant and members desperately hunt for ways to predict a show's success before they pour hundreds of thousands of dollars into its production. "This pyramid of uncertainty produces a paradox: The networks place a premium on rationality, searching for seemingly systematic, impersonal, reliable ways to predict success and failure. ${ }^{\text {n155 }}$

However reassuring such conventions might be to marketers of television content, their actual value in practice is quite limited. First, the empirical research has severe limitations in its use in market applications. ${ }^{156}$ Second, despite the glut of numbersoriented research available to them, programmers continue to rely on their intuition and experience in making decisions about shows. "Most research confirms what most broadcasters already know. However, with the inherent risks in our business, research can become yet another crutch to ease the weight of decision making. Many broadcasters abuse the process by utilizing it to hide from reality and make fuzzier the lines of responsibility." 157 Indeed, one commentator argues that executives frequently use testing as a strategic tool to reinforce already existing conventions and intuitions:

The tool has its uses. When it confirms what some executives already think, the test amounts to an argument with a special aura, conferring the gloss of facts and figures on hunches and guesses. As Harold Wilensky points out about executives in general, "They throw in their 'research' staff ritualistically, much as a tribal leader, embarking on a war, calls on the shaman for supporting incantation. ${ }^{n 158}$

Them, Now You Don't, PHILA. INQUIRER, Nov. 21, 1993, at H1.

${ }^{154}$ For the 1991-1992 season, the average production cost of a half-hour filmed series was $\$ 950,000$, up more than $12 \%$ from the previous season. See Steve Coe, Production Deficits Top $\$ 464$ Million, BROADCASTINC \& CABLE, June 8, 1992, at 4 . The average production cost for half-hour taped shows rose $37 \%$ in the 1991-1992 season to a whopping $\$ 959,000$. See id.

${ }^{155}$ GrTLIN, supra note 136, at 31 .

${ }^{156}$ See id. at 49-55 (discussing flaws in representativeness in Nielsen ratings and the industry's misuse of statistical audience analyses).

${ }^{157}$ WIMMER \& DOMINICK, supra note 150, at 300 (quoting Steve Berger, President, Nationwide Communications Inc.).

${ }^{158}$ GITLIN, supra note 136 , at 44 . Gitlin describes how producers will sometimes intentionally include an exciting opening scene in a pilot to excite test audiences and thereby skew the overall results in favor of the show. See id. at 45 . Low ratings can also give network executives a convenient excuse to cut a show, "thereby deflecting some of the suppliers' anger onto the hapless research department." Id. 
In the final analysis, decision-making in the program selection process remains highly subjective. The television industry operates under a startling atmosphere of uncertainty and ignorance: the reality is that television is "a business that offers so little firm grounding in ethics, aesthetics, or rationality. ${ }^{159}$ As a result, much of what television decision-makers do is a grand attempt to find, or even create, islands of rationality and reliability in an evershifting sea of uncertainty.

\section{Making Television: The Producer's Medium}

Although it is difficult, if not impossible, to identify a single author or artist responsible for a television show, the production process includes a number of key players. To facilitate an understanding of how shows are developed, an examination should begin with the individuals most responsible for what appears on television screens every night-the television producers. ${ }^{160}$

The job description for producers reveals the wide range of creative ability, people skills, and technical talent necessary to fill the role:

[The producer is the] person in charge of a TV production, who establishes the working spirit and dictates the standards to be met. Ideally, as head of the creative team, the producer is both businessman and artist, caring about administration and budgetary details while nurturing the talent and providing the vision for the project. $^{161}$

\section{${ }^{159} I d$. at 22.}

${ }^{160}$ This organization in the medium of television differs from the film context where directors wield the greatest authority over a project. See CANTOR, supra note 137 , at 8 . One unfortunate limitation of focusing on entertainment producers is that it restricts the scope of the inquiry to dramatic series, comedies, and other fictional programs. To compensate for this shortcoming, throughout the following discussion, as well as throughout this Comment, cross-references to news and other nonfiction programming are included where applicable.

${ }^{161}$ Les BRown, The New York Times EnCyClopedia of Television 342 (1977). Robert and Maxine Reed offer a similar, although more comprehensive, informal job description in The Encyclopedia of Television, Cable, and Video:

This title is one of the most overused in the television industry. Many claim it, often on a temporary basis. A true producer, however, is the overall manager of an individual television production and the person who conceives and develops ideas for programs. ... A producer is usually a skilled professional who may generate a series of shows, a single program, or a segment of a larger project. Most commercial and [public television] (PTV) stations employ full-time producers. The responsibilities of the position include the development of ideas and scripts, and the selection of 
In terms of their day-to-day duties, producers are responsible for the principal features of the production process, including story selection; the hiring of writers, directors, cast, and other staff; and overseeing the final editing of the show. ${ }^{162}$ Although no individual ever wields exclusive power over any program, the producer's role is probably the most influential in terms of creative and business control. ${ }^{163}$ Indeed, consistent with the descriptions above, industry insiders often refer to television as the "the producer's medium. ${ }^{\text {164 }}$

Despite their apparent position of authority in the production process, producers are subject to many constraining pressures and demands. In The Hollywood TV Producer: His Work and His Audience, an intensive sociological study of Hollywood television producers, Muriel Cantor illustrates how these particular members of the art world stand at the vortex of the production process and must surrender their individual creativity and control to other interests:

[B]ecause the producer is part of a large, complex bureaucratic organization, he does not have complete control. He is a working producer-a man in the middle between those above him in the networks and production companies and those he supervises in the production crew. As a representative of management, he must fulfill the goals of the organization. Ideally, the producer has responsibility for the creative aspects of the show, but this is always delegated authority because even when a man owns, creates, and produces his own show, the network retains the right to final approval of scripts, casts, and other creative and administrative

performers and directors. Producers also determine the specific approach and format of each production.

They must keep programs within budget and on schedule, handle clearances, order technical facilities and equipment, and schedule rehearsals. Producers are also responsible for the contracts with performers, the coordination of production assignments, and the supervision of directors.

Robert M. REEd \& MAXINE K. REed, The ENCYClopedia of Television, CABle, AND VIDEO 434 (1992).

${ }^{162}$ See Charles R. Wright, Mass Communication: A Sociological PerspecTIVE 67 (1986) (discussing CANTOR, supra note 137).

${ }^{163}$ See id. (describing the television producer as a powerful force in television from a creative and executive standpoint).

${ }^{16}$ NEWCOMB \& ALLEY, supra note 148, at 57; see also CANTOR, supra note 137, at 112 ("Television is seen as a producer's medium, as feature films are a director's medium, because the producer is the final arbiter of controversies and is the one person responsible for those decisions about the unexpected that must be made quickly."). 
matters. ${ }^{165}$

Producers face the conflicting pressures and interests of writers, directors, actors, and actresses, ${ }^{166}$ as well as the regulations of various organized labor groups, ${ }^{167}$ television pressure/activist groups, ${ }^{168}$ audiences, ${ }^{169}$ and the networks. ${ }^{170}$ Of these, the networks exercise the greatest influence over program content. ${ }^{171}$ Although other art world members constrain producers' autonomy, they do so in terms of the "craft" aspects of the production process. ${ }^{172}$ The conflicts between producers and their fellow professionals in production center around relatively discrete issues of quality and creativity; in contrast, producers' relationships with the networks typically involve larger issues of the political and artistic freedom to present certain ideas in a show. ${ }^{173}$ These limitations are a direct result of the networks' profit-motivated influence on production. As previously noted, ${ }^{174}$ the networks retain the final say on most production matters. Thus, the conflicts that arise in the producer-network context are instrumental in explaining the industry's reliance on violence as a visual convention.

\section{The Domestic and Intermational Markets for Violence}

Within the context of the search for rationality, violence plays a critical role because of its time-worn use as a means for capturing the attention of viewers. In his history of television, Tube of Plenty: The Evolution of American Television, Erik Barnouw traces the

${ }^{165}$ CANTOR, supra note 137 , at 8-9.

${ }^{166}$ See id. at 91-115 (analyzing the relationship of the producer with otherswriters, directors, and actors-who are also working in the craft aspect of production).

${ }^{167}$ These labor groups include the Writers Guild and the Screen Actors Guild. See id. at 95-105 (explaining how guild regulations concerning scriptwriting and screen credits can determine whether producers rewrite scripts).

${ }^{168}$ See id. at 34-37 (describing producers' vulnerability to attacks on controversial content from pressure groups).

${ }^{169}$ See id. at 164-87 (examining how the producer's perception of the viewing audience affects content selection).

${ }^{170}$ See id. at 116-43 (describing clash of bureaucratic network values with producers' professional interests).

${ }^{171}$ See Albert, supra note 4, at 1310-11 (explaining how political pressures led a 1977 House subcommittee to reject a controversial report placing the blame for television violence primarily in the hands of the networks).

172 See CANTOR, supra note 137, at 91 (explaining the dichotomy between the craft aspect and the business aspect of production).

${ }^{173}$ See id. at 113 (stating that " $\left.\mathrm{t}\right]$ he major complaint about producing was the lack of political and artistic freedom").

${ }^{174}$ See supra text accompanying notes 160-65. 
development of this convention to the origins of the medium in the late 1950s. ${ }^{175}$ At that time, the newly formed Writers Guild of America West ${ }^{176}$ "tabulated the announced needs of producers and made it clear that hero-villain drama was about all that was wanted. ${ }^{\text {177 }}$ Most notably, these formula dramas almost always included a final chase scene

in which [the villain] was subdued by fistfight, gunplay, knife battle, lariat strike, karate action, or secret weapon.... There seemed to be an unspoken premise that evil men must always, in the end, be forcefully subdued by a hero; that the normal processes of justice were inadequate, needing supplementary individual heroism. ${ }^{178}$

This initial enthusiasm for violent drama was reinforced by subsequent ratings successes. In particular, the $A B C$ network, which was struggling to compete with NBC and CBS at the time, found violent programs such as The Untouchables, Cheyenne, and The Rebel to be an effective means to steal ratings points from the competition. ${ }^{179}$ The response from the competitors came swiftly in the form of orders from executives to network foot soldiers to create their own action telefilms: ${ }^{180}$

The ABC-TV concentration on action, which later became known in government circles as the "Treyz trend," was rivaled at CBS-TV by an "Aubrey dictum." Aubrey demanded action but wanted girls to be a part of it. One staff member summarized the dictum as "broads, bosoms, and fun." NBC apparently dared not leave the field to its rivals and this led, according to later government studies, to a "Kintner edict." ${ }^{181}$

175 See ERIK Barnouw, TUbe of Plenty: THE Evolution of AMERICAN TELEvision 215-16 (1975) (explaining that telefilms in the late 1950s provided violent hero-villain conflicts in quantity).

${ }^{176}$ The Writers Guild of America, the union representing more than 10,000 writers in television, radio and film, consists of two units, Writers Guild of America West ("WGAW") and Writers Guild of America East ("WGAE"). See BROWN, supra note 2 , at 474 .

${ }^{177}$ BARNOUW, supra note 175, at 215.

${ }^{178} I d$.

${ }^{179}$ See id. at 261 (noting that most of $A B C$ 's rating successes were violent).

${ }^{180}$ See id. at 261-65.

${ }^{181}$ Id. at 264 (Treyz, Aubrey, and Kintner were presidents of ABC, CBS, and NBC respectively); see also Levy, supra note 53, at C1. Levy, a former NBC executive in charge of network programming, resigned from the network in 1961 in protest over the "Kintner edict" and the network's attempt to cover up the policy of adding sex and violence to its programming. Later that year, Levy testified extensively before the Senate subcommittee on juvenile delinquency regarding the "Kintner edict." The 
Further fueling the drive toward violence was the development of foreign broadcasting systems, and hence foreign markets for American programming. Because the U.S. television production system developed so early and enjoyed such extensive economies of scale compared to other countries' systems, the "evolution of American involvement with television abroad can be understood within the concept of Americans offering, at an acceptable price, what would be substantially more costly to do locally. "182 As early as 1958, the advertising agency of Foote, Cone \& Belding was monitoring the development of potential foreign markets as countries began purchasing American telefilms in small handfuls to support fledgling broadcasting systems hungry for programming. ${ }^{183}$ Less than two decades later, in 1973, a Finnish researcher could identify only five countries with television systems that were not carrying any U.S. programming. ${ }^{184}$

The immediate obstacle facing American entries into these markets, of course, was the language barrier. Although dubbing and subtitling operations and techniques proliferated to meet the new demand, foreign distributors, namely the television networks and major film companies, took advantage of the uniquely universal language of action/violence. ${ }^{185}$ While comedies or news program-

testimony, which was taken behind closed doors, was never publicly released. Kintner apparently was never asked about the policy during his testimony before the same committee. See id. at C4.

${ }^{182}$ WILliam H. READ, AMERICA's MASS MEdiA MERCHANTS 90 (1976); see also Coco Fusco, Telepictures: An Interview with Josh Elbaum, in Global Television 35, 39 (Cynthia Schneider \& Brian Wallis eds., 1988). Fusco quotes Josh Elbaum, an international sales executive for Telepictures, a domestic and foreign distribution company:
"I want to mention that the primary reason why companies like this exist is that we offer foreign stations, particularly in the Third World, in underde- veloped countries, materials which if they were to make on their own would cost substantially more money. Local production is outrageously more expensive. For a country like Jamaica to be able to finance the production of ten hours of local programming is simply out of the question. That's the real reason we exist."

Id.

${ }^{183}$ See BARNOUW, supra note 175 , at 230.

${ }^{184}$ See READ, supra note 182, at 23 (listing Mainland China, North Korea, North Vietnam, Albania, and Mongolia as the five countries). "In effect, any U.S. TV show preserved on film is a potential export and nearly every such program is available for a price from a distributor." Id. at 24. Although outside the scope of this Comment, the problem of U.S. dominance of the international video market also raises interesting protests of cultural imperialism. See generally GLOBAL TELEVISION, supra note 182.

185 See BARNOUW supra note 175, at 231; READ, supra note 182, at 71 (describing 
ming often presume some familiarity with American culture or current events, action dramas require no such knowledge. ${ }^{186}$ "Climactic gun battles or fist fights, following a chase up a fire escape or down a canyon . . . conveyed their meaning readily in any city or hamlet on the globe," explains Barnouw. ${ }^{187}$ Indeed, in 1972 the estimated weekly world audience for the NBC hit western Bonanza was $\mathbf{3 5 0}$ million viewers. ${ }^{188}$

Today, satellite technology has raised the potential for profit enormously through a phenomenon known as "sequential marketing," through which a single program or film is marketed in the international market first to individual theaters, then cable and satellite systems, then videocassette distributors, and finally public broadcasters: ${ }^{189}$

In terms of the new technology, you can do one trip, speak to one company, and the show's on in thirty million houses. Before, you had to go to all of the outlets to make things available to those thirty million people. That's a lot of time, and a lot of money. The new technology gives an additional source to sell things to. ${ }^{190}$

action-adventure programs as "the most saleable American programs abroad").

${ }^{186}$ See BARNOUW, supra note 175, at 231 (noting that while some comedy series were "international successes, series emphasizing action rather than dialogue were far more translatable").

${ }^{187}$ See id. Barnouw notes that

[b]y 1958-59 a television writer could scarcely find a market for any other kind of material. That winter's Television Market List, issued for its members by [Writers Guild of America West], listed 103 series, of which 69 were in the action-crime-mystery category. They were peopled by cowboys, policemen, and detectives whose terse words would issue in many languages from the screens of the world.

Id.; see also Jonathan D. Tankel, Program Production for Export and the Domestic Market: Authorship in The Avengers, in MAKING TELEvision, supra note 150, at 81, 83-84. Tankel discusses the "mid-Atlantic series format" for creating a program suitable for the international market:

"The formula is well known. It must be on film so that print copies are available. Picture quality and definition must be [good], story structure modified to include the maximum number of action sequences-thus partially surmounting the language barrier. Story content must be reduced to a simple contest between good and bad, instantly recognizable and unequivocal in resolution."

Id. (citation omitted) (quoting British television writer Eric Paice).

${ }^{183}$ See READ, supra note 182 , at 24.

${ }^{189}$ See Fusco, supra note 182, at 38.

${ }^{190} \mathrm{Id}$. 
Most recently, the networks have added a new avenue of access to international markets through the direct purchase of foreign broadcasting systems. ${ }^{191}$ As international markets continue to expand, the incentive to produce easily translatable violent programming is likely to increase. ${ }^{192}$

\section{E. Socialization of Network Standards}

Within the logic of rationalization, it is no surprise that the convention of violence born in the infant years of the industry and reinforced by domestic and international market forces continues today. ${ }^{193}$ With the passage of time, however, a new concern is that members of the art world (most importantly the producers, writers

${ }^{191}$ See Richard W. Stevenson, Foreign Horizons Lure U.S. Broadcast Networks, N.Y. TIMES, Nov. 15, 1993, at D1 (reporting on U.S. broadcast networks' increased involvement in overseas television markets).

${ }^{192}$ At the same time, however, recent developments in the international scene indicate some foreign governments' willingness to censor violent televised material and restrict the importation of American violence. For example, at the end of 1993, Canadian broadcasters and regulators agreed on a set of "voluntary" regulations that restrict the presentation of televised violence. See Canadians Adopt Code, supra note 59 , at 3 (noting that the Canadian regulations ban "any depiction of gratuitous violence").

Overseas, both France and Spain recently imposed limits on foreign music and movies. See Roger Cohen, France and Spain Impose Quotas, N.Y. TIMES, Dec. 22, 1993, at C15 (reporting French Senate's approval of law requiring radio stations to play a minimum of $40 \%$ French music, and Spanish Parliament's passage of restrictions on dubbing and exhibition of American motion pictures); see also John Bates \& Alan Citron, Hollywood Left Out of Picture in Costly Blow, L.A. TIMES, Dec. 15, 1993, at A1 (reporting impact of negotiators' failure to include entertainment industry in General Agreement on Tariffs and Trade). For a discussion of earlier European Community restrictions on the importation of cultural products, see Jon Filipek, "Culture Quotas": The Trade Controversy over the European Community's Broadcasting Directive, 28 STAN. J. INT'L L. 323, 325 (1992) (discussing European Community's limitation of member states' importation of foreign television programming); Suzanne M. Schwarz, Television Without Frontiers?, 16 N.C. J. INT'L L. \& COM. REG. 351, 357-62 (1991) (explaining origins of European Community's "Television Without Frontiers" Directive, and its desire "to protect Europe's cultural identity from the onslaught of Hollywood programs" and to correct the U.S. entertainment trade surplus with Europe).

${ }^{193}$ For a discussion of how format and formula constrain American television content, see Ann Swidler et al., Format and Formula in Prime-Time TV, in MEDIA, AUdiENCE, AND Social Structure 324, 335 (Sandra J. Ball-Rokeach \& Muriel G. Cantor eds., 1986) (describing how the need to sell advertising in the American system fosters reliance on regularly scheduled serials that inhibit creativity and diversity in programming). The authors argue that "for American television, the commitment to continuing series and serials has restricted the ways television can use the traditional formulaic resources of the culture." Id. 
and other craft members who are primarily concerned with product quality) have internalized this convention as a norm of the production process.

Various researchers have identified the phenomenon of the "socialization of work" ${ }^{194}$ in the context of mass media journalists. ${ }^{195}$ Under this model, product policies, standards, and expectations are communicated to members of an art world largely through the informal process of on-the-job socialization. For example, in the newsroom context, reporters are more likely to learn the organization's news philosophy from indirect experience than formal directives or training: "Professional journalists, like their consumers, are educated by what they observe in their own medium. A new reporter seeing what kind of stories get on page one with bylines or are aired during prime-time news does not have to be told what 'news' is for that particular organization."196

Within the complex structure of a production process, with many layers of decision-making, members of an art world learn to censor their creativity to conform to the expectations of those above them in the chain. John Ryan and Richard Peterson have described this type of behavior within the framework of "the product image. ${ }^{p 197}$ Production artists, under this theory, "shape a piece of work so that it is most likely to be accepted by decision makers at the next link in the chain. ${ }^{n 98}$ In Ryan and Peterson's framework, the notion of the "product image," rather than the common aesthetic of an art world, or the directive of an entrepreneur, drives the production process and its final output. ${ }^{199}$ Of course, the tendency in such a system is the production of "works that are much

${ }^{194}$ For an overview of this concept, see WRIGHT, supra note 162, at 73-83.

195 See Ben H. Bagdikian, Professional Personnel and Organizational Structure in the Mass Media, in MASS COMMUNICATION RESEARCH: MAJOR ISSUES AND FUTURE DIRECTIONS 122-42 (W. Phillips Davison \& Frederick T.C. Yu eds., 1974); Warren Breed, Social Control in the Newsroom: A Functional Analysis, 33 SOC. FORCEs 326, 32635 (1955).

${ }^{196}$ Bagdikian, supra note 195 , at $122-23$.

${ }^{197}$ John Ryan \& Richard A. Peterson, The Product Image: The Fate of Creativity in Country Music Songwriting, in Indviduals IN MASS MEdia ORGanizations: CREativity AND Constraint 11, 24-25 James S. Ettema \& D. Charles Whitney eds., 1982). Ryan and Peterson offer the product image framework as an alternative to the traditional assembly line, craft and entrepreneurship, convention and formula, and audience image and conflict models. See id.

193 Id. at 25 .

199 Although this model does not require the common set of conventions or values presumed in Becker's art world model, repeated use of product images can lead to the development of established norms much like those found in art worlds. 
like the products that have most recently passed through all the links in the decision chain to become commercially successful. ${ }^{200}$ In the television environment, this theory suggests a rationale for the persistent creation of violent content, even without explicit network orders.

Indeed, evidence of the socialization of product expectations among producers is found in studies of television producers. Cantor confirms that, much as in any other mass communication process, "[t]o remain in production, a producer must be able to conform to the changing directives of the networks. ${ }^{201}$ More importantly, Cantor and others have found that producers, who presumably are ultimately responsible for delivering programs to the viewing audience, evaluate their products in terms of the product image framework described above, ${ }^{202}$ that is, will the networks and advertisers approve of this show?

[S]ome television producers may be communicating to the secondary audiences (reference groups)-those in control of the medium, the network executives and advertising agencies-rather than directly to the primary viewing audience. Each network does maintain script control and has an office that censors scripts. A producer may learn policy and what is expected of him and select stories accordingly after a number of his scripts have been changed by the censor's office. ${ }^{203}$

In light of the networks' historical reliance on (and approval of) violence as a device to garner ratings, it is not surprising to find producers have submerged their own aesthetic values in favor of the prevailing product image. ${ }^{204}$

\footnotetext{
${ }^{200}$ Ryan \& Peterson, supra note 197, at 25.

201 CANTOR, supra note 137 , at 149.

202 See supra notes $131-35$ and accompanying text.

${ }^{203}$ CANTOR, supra note 137 , at 31 .

${ }^{204}$ Cantor points out that
}

[t]hose producers who are committed to particular artistic and ethical values have trouble remaining in the commercial field. A well-known producer of a series presently on the air left the field of children's programming because he could not reconcile what he considered the networks' lack of social conscience with his own ideas of good craftsmanship and content. However, he is an exception.

Id. at 149. 


\section{F. Summary}

The production of culture is a complex process involving the intersection of institutions, occupations, laws, technology, and market forces. In addition, cultural products are shaped by the conventions that prevail in a particular art world. In theory, producers are the artisans that enjoy authority in overseeing the craft and business aspects of television production. These individuals, however, are subject to great pressure from the networks, which in turn must deal with both domestic and international market pressures driving the business side of the industry. Because the structure of the industry favors the pursuit of ratings and audience shares for advertisers over the presentation of beneficial programming, those associated with the "craft" aspects of production compromise or even suppress their natural notions of quality.

The structure of television, then, produces a self-perpetuating. cycle that maintains the status quo through the use of conventions and rationalization. Homogeneous, unimaginative, and oftentimes violent programming is the natural product of this cycle. Breaking this cycle is the key to reducing violent content and encouraging new forms of video expression. The following Part will suggest ways policymakers can develop a comprehensive structural strategy to do just that.

\section{Proposed Solutions}

\section{A. Does Violence Sell?}

One of the more puzzling mysteries viewers face is why critically acclaimed programming fails to generate the same ratings as conventionally "less serious" shows. ${ }^{205}$ Although the networks"

${ }^{205}$ Consider the case of Frank's Place, a sitcom that premiered in the fall of 1987 and featured the life of an African-American history professor who inherits a $\mathrm{New}$ Orleans restaurant. The show, which starred Tim Reid (of WKRP in Cincinnati fame), won praise from a diverse range of sources: critics declared the show "revolutionary," "a sitcom of uncommon freshness . . a 'black' show of uncommon dignity," "the first black show since Roots to take Black culture seriously." Richard Campbell \& Jimmie L. Reeves, Television Authors: The Case of Hugh Wilson, in MAKING TELEvisION, supra note 150, at 3, 4 (quoting Michael Pollan, a writer for Channels magazine, and Alvin Poussaint, the Harvard psychiatrist who consulted on The Cosby Show). The trade publication Electronic Media ranked Frank's Place the third best show of 1987, behind L.A. Law and The Wonder Years. See id. Nevertheless, CBS canceled the show in October 1988, barely more than a year after its debut. See id. Despite a strong start in the ratings, by the end of the show's run, Frank's Place fell among the lowest rated 
impatience with poorly rated shows ${ }^{206}$ partially explains the disappointing performance of some innovative nonviolent programs, the larger question remains: do viewers prefer violence? The answer to this question is critical to the policy debate on this issue. If viewers want violence, then there really isn't much to debate-the public is getting what it wants. If, however, audiences actually prefer more diverse, nonviolent programming, then the oversupply of violence is an indication of market failure in the industry-viewers are getting lots of what they don't want-and structural changes are in order.

The limited amount of empirical studies testing this point indicate that in fact violence is not the pied piper that industry executives have assumed it to be. ${ }^{207}$ A study of more than 200 prime-time network dramatic shows aired between 1988 and 1993 revealed that violent programs consistently garner lower ratings than nonviolent fare. ${ }^{208}$ An earlier investigation examined the relationship between violent programming and viewer satisfaction through two independent studies: one testing the correlation between the violence levels and Nielsen ratings of actual programs and the other comparing laboratory subjects' reactions to either an uncut version of a violent program or an edited nonviolent version of the same program. ${ }^{209}$ Both studies failed to demonstrate a correlation between violent content and popularity with viewers.

Although the explanatory power of such studies is obviously limited, ${ }^{210}$ such evidence tentatively suggests that the restriction

network shows on the air. See id.

Even Senator Simon has conceded his frustration with a viewing audience that is "a little inconsistent." Feran, supra note 5, at 6A. "The audience says there is too much violence, and at the same time they turn on the set and watch the violence." Id.

${ }^{206}$ See Storm, supra note 153, at H1 (stating that programmers are often forced to cancel poorly rated shows quickly in an era when network television is competing with cable, independent stations, video games, and VCRs).

${ }^{207}$ See Gerbner et al., supra note 7, at 171; see also Ed Diener \& Darlene DeFour, Does Television Violence Enhance Program Popularity?, 36 J. PersonaltTy \& SOC. PSYCHOL. 333, 339 (1978) (reporting experimental findings suggesting "that program violence has little impact upon popularity and liking").

${ }^{208} \mathrm{See}$ George Gerbner, Highlights of the Television Profile No. 16, at 2-3 Jan. 27, 1994) (unpublished manuscript presented at the National Association of Television Program Executives' Annual Conference, Miami Beach, Fla.) (on file with author). The average Nielsen rating for violent programs was 11.1 , see id. at 3 , while that for nonviolent programming was 13.8. See id. Ratings represent the percentage of households in a given area that are equipped with a television and are tuned to a certain program. See BROWN, supra note 2, at 449.

${ }^{209}$ See Diener \& DeFour, supra note 207, at 333.

${ }^{210} \mathrm{See}$ id. at 336-37, 339-40 (acknowledging criticism of Nielsen ratings as a 
of program choice, not natural preferences, is what leads viewers to tune into violent programming: "A viewer would have to be quite diligent to select nonviolent programs. Heavy viewers would have the least choice."211 Another study of viewer preferences suggests that violence is only part of a larger public dissatisfaction with lowquality, homogenous program options. ${ }^{212}$ The solution the researchers recommend parallels that suggested in this Comment:

Low level and homogenous programming are much more difficult problems to solve than objectionable content. Rather than mere reduction of specific subject matter, they require structural change .... Ironically, only structural changes can truly resolve consumer complaints about content. Content complaints basically stem from insufficient program variety. This means that at any given time viewers with different tastes and needs are all forced to choose from a few very similar programs. ${ }^{213}$

The research thus supports the strategy of increasing program choice, rather than the regulation of existing content, as a response to the issue of television violence.

Faced with the choice between violent material and violent material, then, viewers not surprisingly reach for what is available. Greater diversity in program selection combined with more precise measures of viewer preference could lead program executives to reformulate their assumptions about what people want to see. ${ }^{214}$

measure of viewer reaction to content and limitation of laboratory testing involving only a single program).

${ }^{211}$ Nancy Signorielli, Selective Television Viewing: A Limited Possibility, 36 J. CoмM. 64,74 (1986). Signorielli argues that

[w]hat is most important is that even though there are some differences in programming, the average viewer has relatively little opportunity to exercise any kind of choice in viewing. The data point clearly to the fact that much less programming time is devoted to serious dramas and to situation comedies than to action-adventure programs. Thus, given the current network programming practices in the United States, it is almost impossible to find a heavy viewer who is not exposed to a substantial amount of violence and action-adventure programming. In this sense, television Id. programming is necessarily a relatively non-selective activity.

${ }^{212}$ See Deanna C. Robinson et al., A Consumer Model for TV Audiences: The Case of TV Violence, 6 COMM. RES. 181, 196 (1979).

213 Id. at 197.

${ }^{214}$ The networks confidence in ratings may be one factor confounding their understanding of viewer preferences. Present ratings measure only the number of viewers tuned in to a particular program: they tell decision-makers nothing about the quality or nature of an audience's involvement with a program. See Barrie Gunter, On the Future of Television Ratings, 37 J. BROADCASTING \& ELECTRONIC MEDIA 359, 360 


\section{B. The Possibility for Change}

Despite the existence of a firmly entrenched culture of violence as presented in the preceding Section, change is possible:

[T]here is the possibility of creativity and innovation in commercial television because, thanks to both organizational and human factors, ratings, reliance on track records and the use of formulas do not-and, in fact cannot-completely routinize the television production process. A certain amount of inspiration or entrepreneurship is still necessary. ... It is the sad, yet somehow sweet, irony of television that the industry produces these successes despite itself. ${ }^{215}$

Such an optimistic perspective is supported by the real life experiences of producers who have demonstrated that innovation and creativity can surface once the structural fetters of the industry are removed. Consider, for example, the experience of John Mantley, executive producer of the series Gunsmoke, who faced the national antiviolence campaign of the 1960s:

"I wanted to quit Gunsmoke, but, when the violence restrictions came in, nobody knew what to do with the show and they got out of the way because they didn't think I was going to be able to save it ... and nobody wants to be associated with a failure! In one

(1993) ("Indeed, most television ratings systems, technically speaking, measure viewers' presence in the room with the television set switched on, rather than actual viewing." ). New, experimental, qualitative audience measures that assess viewers' involvement with a program in terms of appreciation, loyalty, and impression could provide "far more subtle information . . . about a program's value to viewers that can be of use to program makers, broadcasters, and advertisers." Id. at 361 (citation omitted) (arguing that in the approaching age of increasing television channel capacity, traditional ratings systems will become less and less valuable as the size of program audiences diminishes). An interesting hypothesis for future study might be that viewers are attracted to and content to view violent programs when flipping casually through channels looking for anything to fill the screen while doing the dishes; but when people make deliberate choices about programs they intend to engage in, they crave more meaningful programming. In other words, people tune in to violence as background entertainment, but, as a general matter, viewers seek more substantive fare.

${ }^{215}$ Robert Pekurny, Coping with Television Production, in INDIVIDUALS IN MASS MEdia ORganizations: CREATIVITY AND CONSTRAINT, supra note 197, at 143. Consider as well Becker's suggestion that

[c]onventions make collective activity simpler and less costly in time, energy, and other resources; but they do not make unconventional work impossible, only more costly and difficult. Change can and does occur whenever someone devises a way to gather the greater resources required or reconceptualizes the work so it does not require what is not available.

BECKER, supra note 127, at 35 . 
sense, that is good, because I love it if they don't 'help.' But, you see, when those violence restrictions came in, I was suddenly able to have the freedom to make shows of my own. Can you imagine any network permitting me to make a show about a Jewish patriarch in a western, not just about the patriarch, himself, but about his dedication to the Torah?! I mean, it was impossible before those restrictions came in. Or to make a show called 'The Fires of Ignorance,' about the need for compulsory child education. All of these things I was able to do because nobody knew what to tell me to do with the show. ${ }^{216}$

This final Section will suggest a number of approaches designed to free producers and the industry from the structural constraints outlined in Part IV. It is worth repeating here the notion that excessive violent content is a symptom of the larger problem of structural censorship within the television industry. The solution to the problem of violence and censorship is not to impose further content-based restrictions on the production process, but rather to remove, or reduce, the existing structural constraints. The actions described below require more patience than labeling requirements or outright bans on violent programming, but these proposals properly recognize the range of structural influences on program content. Because structural change is less tangible than highly visible labeling approaches, legislators are unlikely to champion these proposals before their colleagues and constituents. Whatever their political viability, however, these sorts of structural mechanisms are the only means available for improving the state of television without invoking content-based measures that threaten to violate both the law and sound policy.

Although the structural approach might lead to a variety of policy proposals directed at various constraints on the production system, this Section will focus on two of the most prominent aspects of the structural model: the influence of advertising and the constraints on creative labor in the production process. Reducing the driving influence of advertisers and eliminating current constraints on creative personnel should be top priorities for anyone concerned with real change in the television industry.

${ }^{216}$ NEWCOMB \& ALLEY, supra note 148, at 126. 


\section{Reducing Advertising Influence/Increasing \\ Viewer Participation}

We aren't going to get rid of violence until we get rid of advertisers. The advertiser wants something exciting with which to get the audience. Violence equals excitement equals ratings. As the population has grown, the number of TV viewers has not increased proportionally, so "tougher stories" is the word today. ${ }^{217}$

The key to breaking the cycle of market influence depends largely on measures aimed to challenge the traditional reliance of networks and advertisers on violent programming to generate mass audiences. Removing or reducing advertiser influence on product content is the most obvious, but also the most difficult, avenue for change in the industry. Any strategy to create greater program diversity must begin by altering the incentive structure within the dual product market framework to encourage the industry to value viewer preferences as much as, if not more than, delivering ratings to advertisers. In recent years, a number of commentators have proposed schemes consistent with the structural approach and its criticism of advertising's influence over content.

One solution might be to remove the advertisers' ability to sponsor and thereby influence individual programs. One commentator, Patrick Fahey, in discussing mechanisms for reducing the negative effects of product boycotts on network television content, has advocated the adoption of program-blind advertising:

Under this system, advertisers would designate the number of people they wish to address in each demographic category and the network would randomly assign to them commercial spots achieving this level, a procedure which is similar to that currently employed in the upfront market.... The advertiser would be prohibited from choosing or avoiding any controversial or topical programming under the guise of preserving its corporate image. ${ }^{218}$

By removing advertisers' capacity to dictate exactly what shows they wish to sponsor, networks would be far less vulnerable to adver-

${ }^{217}$ Baldwin \& Lewis, supra note 27, at 314 (quoting an unidentified writer for the television show The Untouchables).

${ }^{218}$ Patrick M. Fahey, Advocacy Group Boycotting of Network Television Advertisers and Its Effects on Programming Content, 140 U. PA. L. REV. 647, 691 (1991). Fahey also proposes the establishment of internal network standards and practices departments that include advocacy group members, thereby ensuring those organizations access to program decisions. See id. at 696-708. 
tisers' protests over, or preferences for, aspects of specific shows and would thus be able to exercise greater freedom in determining program content. ${ }^{219}$ Similarly, a program-blind advertising arrangement would compel networks to focus on their aggregate season-long ratings rather than individual program ratings.

In the current environment, networks must abandon low-rated shows because of the difficulty in selling small audiences to firms interested in getting the most bang for their advertising dollars. In a program-blind system, however, because the network retains the discretion to distribute an advertiser's audience preferences over the course of a season, it can combine the audiences of several lower-rated programs to achieve the level desired by an advertiser. This in turn could reduce the incentive for network officials to micro-manage the program production process, thereby giving creative personnel precious breathing space. Because a programblind advertising system removes the pressure on networks and producers to try to make every show a ratings bonanza, this proposal could encourage greater patience and experimentation with programs. ${ }^{220}$

Reducing advertiser influence is, or course, meaningless without simultaneous efforts aimed at increasing viewer participation in programming decisions. One proposal suggests mandating access for citizen-oriented programming: Ralph Nader and Claire Riley have proposed the creation of an "Audience Network," which would be a "nonpartisan, nonprofit corporation open to all citizens for a nominal fee. ${ }^{221}$ The Network would receive one hour of airtime per day on commercial radio and television stations to run programming selected through the democratic process. ${ }^{22}$ Airtime could

${ }^{219}$ One consequence of this scheme, however, might be that the networks, rather than deciding to take greater risks with innovative programming, would adhere even more fervently to established conventions to assure that advertisers could be certain of the type and tone of shows they might be sponsoring in a content-blind system.

${ }^{220} \mathrm{~A}$ simple variation of the content-blind approach could be to limit advertising to time slots before and after, but not during, programs. The European Community has already adopted this type of regulation. See George A. BERManN ET AL., EUROPEAN COMMUNITY LAw: SELECTED Documents 349 (1993). Congress has also recently imposed limitations on broadcast advertising aired during children's programming. See 47 U.S.C. \$ 303a(a)-(b) (Supp. III 1991) (limiting advertising to 10.5 minutes per hour on weekends and 12 minutes per hour during the week).

${ }^{221}$ Ralph Nader \& Claire Riley, Oh, Say Can You See: A Broadcast Network for the Audience, 5 J.L. \& POL. 1, 68 (1988). Nader and Riley include a model statute for the Audience Network following their article. See id. at 87-125.

${ }^{222}$ See id. at 68. 
be apportioned to local community groups, citizen organizations or nonprofit groups such as the Cancer Society or Girl Scouts:

The possibilities for community and national use of air time are numerous. ... Among the many possibilities currently not on the air are programs exploring the effects of the mass media and programs showcasing local and regional culture or traditions. Audience Network could provide thorough and timely information on activities of local, state and federal governmental bodies. Interesting discussions of local, state and national political candidates' views and electronic town meetings, where public officials discuss important issues and get immediate feedback from constituent viewers, are also possible. ${ }^{223}$

While the Audience Network would undoubtedly increase the level of citizen participation in television content, the overwhelming balance of programming (namely, the remaining twenty-three in the day) would continue to be subject to traditional structural constraints. More daring proposals could seek to equalize the balance between public and private television by increasing the amount of time required for Audience Network programming.

A more direct, and certainly more controversial, means of countering the influence of advertising revenues on content might be found in schemes that redistribute revenues to fund public or viewer-responsive programming. Although initially offered as a solution to the effects of advertising on content in the newspaper context, Professor C. Edwin Baker's Tax-Advertising/SubsidizeReaders ("TA-SR") proposal could possibly apply as well to the television industry. ${ }^{224}$ Baker's proposal, designed to counter the newspaper practice of catering to advertisers' needs over readers',

${ }^{223} \mathrm{Id}$. at 71 . Of course, not all programming would necessarily focus on government affairs:

A week's worth of local programming could include a community theater company profile, a documentary on the effects of drought on the region and a program on the impact of smoking on community health. The local chapter of the American Civil Liberties Union could produce a documentary on racial and ethnic tension, and a high school play could be televised. Programming could also include issues such as housing the homeless, pollution, labor unions, social security, veterans' issues and the best and the worst of public schools.

Id. at 71-72.

${ }^{224}$ See C. Edwin Baker, Advertising ANd A Democratic Press $85-91$ (1994). Baker's proposal is based on a thorough presentation of the various ways advertising restricts media content. See id. at 44-70. An earlier version of this proposal is presented in the article, C. Edwin Baker, Advertising and a Democratic Press, 140 U. PA. L. REV. 2097 (1992) [hereinafter Baker, Advertising]. 
would tax newspaper advertising revenues and then redistribute the resulting pool to papers based on circulation: "Papers that received more than an average proportion of revenue from advertising would make an increased payment while those receiving less than the average portion of revenue from advertising would receive a credit either reducing their taxes or possibly resulting in receipt of a payment from the government. ${ }^{\text {225 }}$ The result, Baker argues, would be to 'lessen papers' incentive to respond to advertisers' concerns, and thus increase their incentive to respond to the other purchaser, the reader. ${ }^{226}$ In the television context, a similar plan might tax advertising to help fund noncommercial television, ${ }^{227}$ or perhaps even Nader and Riley's Audience Network organization. Although politically infeasible as a practical solution, Baker's proposal is significant because it points to the necessity of reducing the industry's reliance on advertising revenues to encourage attention to viewer preferences. ${ }^{228}$

In sum, any attempt to improve the diversity of television content must grapple with the imbalance between advertiser and public control over programming. Such efforts will need to include measures to insulate networks from advertiser influences while at the same time substantially increasing the power of viewers to expand and shape television content.

\section{Occupational Constraints: Encouraging Creativity}

On the occupational front, efforts to reduce the production of violent material should focus on empowering the craftspeople involved in television production. Studies of the production process repeatedly identify producers and writers as the last line of creative defense against the commercial interests of networks and advertisers. Strengthening the collective hand of these individuals through existing professional organizations or unions could help level the balance of power between craftspeople and profit-oriented executives. ${ }^{229}$ Strategies for change must counteract the socialization

${ }^{225}$ Baker, Advertising, supra note 224, at 2181 n.285.

${ }^{226}$ BAKER, supra note 224 , at 86 .

227 See id. at 113.

${ }^{228}$ Politically more appealing alternatives to TA-SR systems might create taxes on the sale of television sets to support public television. Such proposals are inadequate, however, because they leave the current advertising structure intact. See id. at 114 .

${ }^{229}$ For example, the Writers Guild of America could negotiate collective bargaining agreements or individual contracts for its members that reserve greater degrees of creative control over program content than is available today. The Guild 
processes that have shaped the occupational roles in production.

The experience of producers who have had the rare opportunity to operate without the usual constraint of network interference is encouraging. For example, Hugh Wilson and John Mantley, two producers who achieved considerable commercial success through formula programming, both succeeded in developing groundbreaking material once they were able to exercise real authority over their projects. In Mantley's case, the freedom came when the network abandoned Gunsmoke in the wake of the 1960s antiviolence campaigns. ${ }^{230}$ In contrast, Wilson bought his own freedom for Frank's Place by negotiating a "complete hands-off deal" with the then struggling CBS network. ${ }^{231}$ Campbell and Reeves suggest that Wilson's ability to retain creative control over Frank's Place fits an established pattern in which financially troubled firms stimulate innovation and experimentation: "A desperate company is more likely to seek out new ideas and new talent, more likely to sponsor experimentation, more likely to take risks-and less likely to interfere in the creative process. ${ }^{\text {232 }}$ This observation suggests an interesting hypothesis: as competition between a growing number of video outlets increases-and the number of firms operating near the margin of profitability increases-the possibility of expanded creative freedom for craftspeople will improve.

As for the present, increasing creative control over programming decisions can take two possible paths. First, policymakers could take measures to facilitate the separation of business and creative interests within media firms. For example, within the broadcast licensing context, the FCC could give preferential treatment to applicants who have provided for formal guarantees of editorial freedom for creative personnel within their organizational structures. Similarly, access to future common-carrier television systems could be conditioned on an applicant firm's agreement to express limitations on business interference in creative matters. These limitations might allow for general network oversight of programming decisions, such as the ordering of general story ideas and series, but would forbid the sort of day-to-day interference that

and other professional associations could also encourage their members to experiment with the medium and avoid reinforcing existing conventions wherever possible.

${ }^{230}$ See supra note 216 and accompanying text.

${ }^{231}$ Campbell \& Reeves, supra note 205, at 8.

${ }^{232} \mathrm{Id}$. 
results in endless squabbles over minute character or plot developments. More radical proposals might require formal organizational autonomy for creative producers and writers.

A second approach to increasing creative control would seek to place increasing business control in the hands of creative personnel who have a greater interest in serving viewers rather than advertisers. ${ }^{233}$ The program output of a network owned exclusively by producers, writers, and actors presumably would look quite different from the fare prevalent today. Like any other network, a creative-owned firm would need to tailor its efforts to insure a threshold level of audiences, but the network controlled by creative people would almost certainly take greater risks with nonconventional programming. ${ }^{234}$ The success of such networks would hopefully stimulate greater experimentation among traditional networks as well.

\section{E. Summary}

Consistent with the principle of the structural approach, efforts aimed at increasing creative influence in programming must coincide with efforts aimed at correcting the imbalance between viewer and advertiser program control. Taken alone, each of the measures suggested above are unlikely to have a measurable impact on reducing violence or promoting diversity. If implemented as part of a comprehensive structural strategy, the effect on the industry could be unprecedented. Policymakers should consider a regulatory framework which incorporates the proposals presented above, as well as others that spring from a structural analysis of the television industry. This will require special efforts to maximize

${ }^{293}$ Professor Baker has advocated this approach as a means of countering the effects of media ownership. See C. Edwin Baker, Mergerphobia, THE NATION, Nov. 8, 1993, at 520, 521. As Baker puts it:

I suspect that meaningless sexual innuendo and constant violence is less what TV writers and directors want to produce than what corporate executives demand in order to maximize their audience or please advertisers. Rather than reduce the current rate of violence through government censorship, we might try increasing ownership or control by people who have a personal stake in the quality, not merely the profitability, of the cultural products.

Id. at 521 .

${ }^{254}$ The chances of this happening would be greatly enhanced if such networks were publicly funded. Even if supported by advertising, however, creative-based networks might be effective at developing innovative programs that advertisers would be excited to sponsor. 
consumer choice in the television information and entertainment markets by removing the constraints (legal, occupational, organizational, market, and technological) on creativity and program diversity that have plagued the medium since its inception.

Although structural change might seem politically implausible, technological developments in the medium provide a convenient opportunity for reexamining the television industry. The changing nature of the video environment is the wild card of the violence dilemma. Speculation regarding 500-channel cable systems has already spawned a new wave of specialized networks. ${ }^{235}$ Perhaps the only near certainty for the future of television is that the new technologies will bring viewers a larger slate of "channels" from which to select their program choices. Whether the increase in channel choices will precipitate an increase in program choices remains uncertain. According to some industry observers, including former FCC chairman Alfred Sikes, "more channels means more opportunities. ${ }^{236}$ Others argue that in a 500-channel environment, violence might become more prevalent than today, as programmers will fall back on the time-worn convention of adding violent material to a show to attract ever-shrinking segments of the viewing audience in an increasingly competitive television market. In this scenario, the "advance" of technology might leave viewers worse off than they were previously. ${ }^{237}$ Either way, the march of

${ }^{235}$ See Lee Winfrey, Coming Soon to a TV Near You, PHILA. INQUIRER, Nov. 23, 1993, at E1, E6 (listing a dozen new channels scheduled to debut in the near future, including three new home shopping channels, a military channel, a golf channel, an all-talk channel, a history channel, a jazz channel, and a "romance classics" channel).

${ }^{236}$ Alfred C. Sikes, Remarks at the International Radio \& Television Society Newsmaker Luncheon, Sept. 19, 1991, available in LEXIS, FEDCOM Library, FCC File, 1991 FCC LEXIS 5003, at *5. Sikes continued:

Commercial success in broadcasting will not be ensured through mindless shows built around sex, gratuitous violence, or the latest effort to exploit bizarre conduct advanced by so-called "talent researchers." . . .

One encouraging sign is the discovery by the Public Broadcasting System (PBS) and some commercial broadcasters and cable network operators. They are discovering that quality programming has more "shelf life" in the new video markets. A new media world of hundreds of channels delivered via broadcast, fiber, and satellite paths will-I predict-place a real premium on quality and resulting "shelf life."

Id. at *6-*7.

${ }^{237}$ With respect to the relationship between technology and advertising, media critics have speculated that new technologies will increase the power of advertisers over consumers:

The fashionable, faux futurism predicts that this time will be different, that this time new media technology will guarantee the individual the upper 
technology provides communications policymakers with a prime opportunity to counteract the homogenizing forces that have ruled television during the latter half of the twentieth century.

\section{CONCLUSION}

During 1993, television violence emerged as an issue of public and private concern. Unfortunately, the resulting policy proposals failed to fully recognize nature of the issue. This Comment has attempted to show that the problem of violence is but a symptom of a more serious problem in the television industry. Structural constraints in the production process, supported primarily by the concerns of advertisers, operate to inhibit program diversity and innovation. The solution to this problem should not be the further suppression of expression. Instead, policymakers should seek content-neutral alternatives that stimulate creativity and access for a wide variety of ideas and shows. Unfortunately, there is no guarantee that such structural strategies will necessarily either reduce the level of violence or increase viewer choice. Until society concedes that it can or must tolerate content-based, reactive measures reflecting both bad law and bad policy, however, these strategies are the most promising options citizens have for improving the video landscape.

This Comment has suggested that current content-based thinking on the dilemma of television violence suffers from a narrow vision of the way television content is shaped by influences in the industry. The structural approach described and advocated herein produces strategies for violence reduction which are more precisely aimed at influencing the root motivations for the production of violence. Particularly in light of changing technologies, communications policymakers should begin considering how the current television structure inhibits program diversity and what can be done to establish a system that encourages greater creativity and variety in the public interest.

hand over the advertiser. Maybe; maybe not. More likely, we'll see these new media renegotiate the power relationships between individuals and advertisers. . . . Advertising will not go away; it will be rejuvenated.

Michael Schrage et al., Is Advertising Finally Dead?, WIRED, Feb. 1994, at 71, 72. 




\section{FROM THE EDITORS}

The following Articles were commissioned for a Symposium devoted to Professor Michael Moore's book, Act and Crime: The Philosophy of Action and Its Implications for Criminal Law (Clarendon Press 1993), the first to present a unified account of the theory of action presupposed by both Anglo-American criminal law and the morality that underlies it. Professor Moore is the Leon Meltzer Professor of Law and Philosophy at the University of Pennsylvania, and is well known for his work in criminal responsibility and natural law.

The Symposium took place on February 17th and 18th, 1994, at the University of Pennsylvania Law School, and the papers presented and debated there were revised for publication in this, the annual symposium issue of the University of Pennsylvania Law Review. The Law Review is honored to have hosted the conference and is proud of the quality of scholarship it generated. We hope that the dialogue established in these Articles will further illuminate a previously murky area of legal thought.

The Editors would like to thank the authors for their participation, and Professor Jay Wallace of the Philosophy Department of the University of Pennsylvania for acting as moderator during the Symposium. 